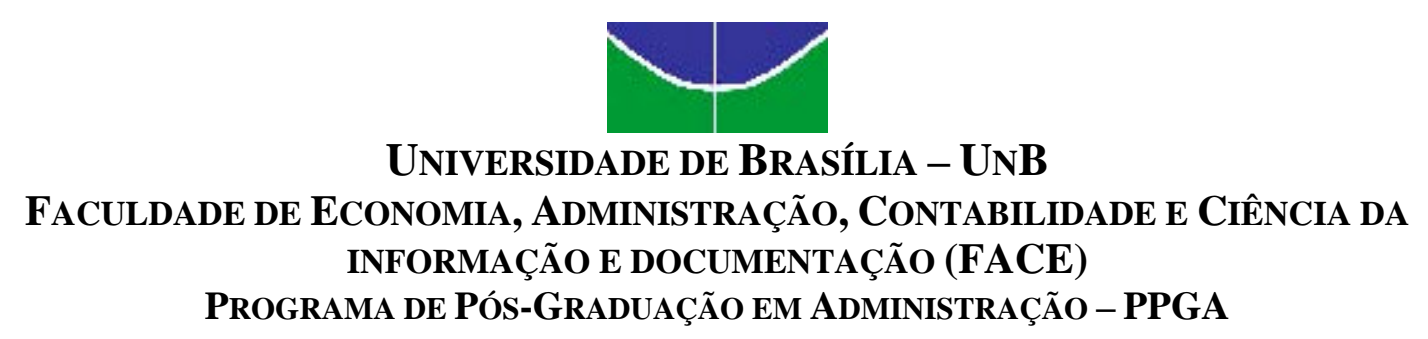

Adriana Hemsing Lima

\title{
IMPACTO DO SUPERÁVIT PRIMÁRIO NOS GASTOS SOCIAIS
}

Brasília - DF

2009 


\title{
AdRiAnA HeMSING LiMA
}

\section{IMPACTO DO SUPERÁVIT PRIMÁRIO NOS GASTOS SOCIAIS}

\begin{abstract}
Monografia apresentada ao Departamento de Administração da Faculdade de Economia, Administração, Contabilidade e Ciência da Informação e Documentação (FACE), da Universidade de Brasília, como requisito parcial à obtenção do grau de Especialista em Orçamento e Finanças Públicas.
\end{abstract}

Orientador: Prof ${ }^{\circ}$ Mestre Francisco Glauber Lima Mota

Brasília - DF

2009 


\section{Adriana Hemsing LiMA}

\section{IMPACTO DO SUPERÁVIT PRIMÁRIO NOS GASTOS SOCIAIS}

Brasília, junho de 2009.

Monografia aprovada por:

Francisco Glauber Lima Mota (Orientador)

Universidade de Brasília, Programa de Pós-Graduação em Administração 


\section{AGRADECIMENTOS}

À Deus, o que seria de mim sem sua presença e seu aperfeiçoamento.

Ao Wesley Aoyama Silva, meu marido, pelo carinho, companheirismo e atenção.

À minha família, que me deu muito carinho e apoio. Em especial a minha sogra, Líria Hitomi Aoyama Silva, que muitas vezes ficou com minha filha Júlia para que eu pudesse efetuar as pesquisas.

À minha filha Júlia Hemsing Aoyama que muitas vezes inundou de alegria onde existia cansaço e desânimo.

Ao professor e orientador Francisco Glauber Lima Mota por seu apoio no amadurecimento dos meus conhecimentos e conceitos que me levaram a execução e conclusão desta monografia.

Aos colegas da pós-graduação, pela ajuda, apoio e consolo.

Aos colegas de trabalho, pelo apoio e compreensão. 
O futuro tem muitos nomes.

Para os fracos é o inalcançável.

Para os temerosos, o desconhecido.

Para os valentes é a oportunidade.

Victor Hugo 


\section{RESUMO}

O presente trabalho tem por escopo o estudo do gasto social e superávit primário nos últimos 9 (nove) anos e se utilizou das técnicas da pesquisa documental para o trabalho de abordagem dos dados. Apesar de a pesquisa documental ser considerada como pesquisa qualitativa, a pesquisa efetuada foi marcada principalmente pelas características da pesquisa quantitativa, pois a coleta de dados se baseou em dados oficiais publicados pelo Governo, permitindo uma análise quantitativa, e objetiva demonstrar se houve redução do gasto social em cumprimento à meta de superávit primário. $\mathrm{O}$ aumento da carga tributária foi justificado pela necessidade de aumento das contribuições sociais, mas o repasse da arrecadação não ocorreu em sua totalidade devido à possibilidade de aplicação da DRU, que tem sido utilizada como auxílio à formação do superávit primário, à despesa financeira, principalmente juros e encargos, e ao atendimento de despesas obrigatórias. A formação do superávit primário tem por objetivo o atingimento do chamado déficit nominal zero o quanto antes possível, e tem sido utilizado como principal instrumento da política fiscal. Há uma demanda crescente de necessidades sociais, porém algumas políticas sociais obtiveram elevação de seus gastos, acompanhando o crescimento do PIB, em compensação, os gastos com saúde e educação não obtiveram a mesma trajetória de crescimento, o que reflete em serviços com menor qualidade do que a esperada pela sociedade. Caso o recurso destinado a formação do superávit primário pudesse ser repassado aos gastos sociais e ao investimento em infra-estrutura, certamente, teríamos um volume expressivo para atendimento das necessidades sociais e uma maior qualidade de vida. Diante do exposto, chegamos à conclusão de que o gasto social foi afetado pela perseguição do superávit primário refletindo em menor repasse de recursos, principalmente, aos serviços de saúde e educação devido à utilização da DRU.

Palavras-chave: gasto social; política social; superávit primário; DRU; vinculação de recursos. 


\section{LISTA DE FIGURAS}

Figura 1 - Composição das receitas orçamentárias .......................................................... 13

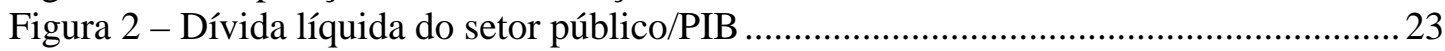

Figura 3 - Carga tributária social federal e gasto social federal ....................................... 29

\section{LISTA DE TABELAS}

Tabela 1 - Discriminação das despesas primárias governo central..... 13

Tabela 2 - Gastos sociais por função e percentual sobre o PIB (2000 a 2004) .................... 37

Tabela 3 - Gastos sociais por função e percentual sobre o PIB (2005 a 2008) ..................... 37

\section{LISTA DE GRÁFICOS}

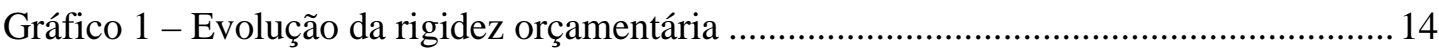

Gráfico 2 - Execução e meta do superávit primário.......................................................... 21

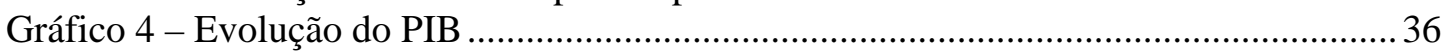

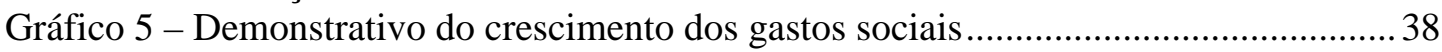

Gráfico 6 - Demonstrativo do crescimento dos gastos sociais, exceto previdência............. 39

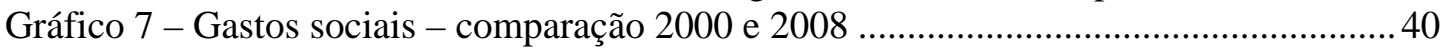

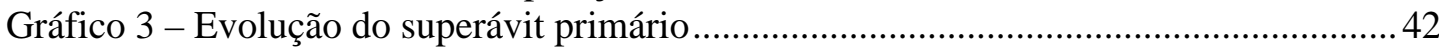

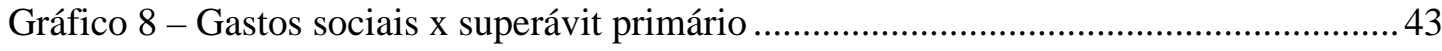

Gráfico 9 - Gastos sociais x superávit primário, exceto previdência social......................... 44 


\section{SUMÁRIO}

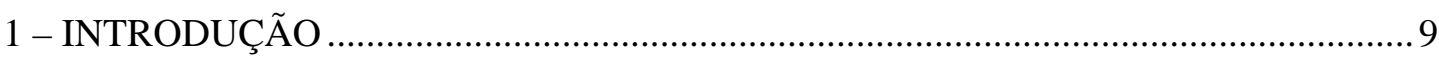

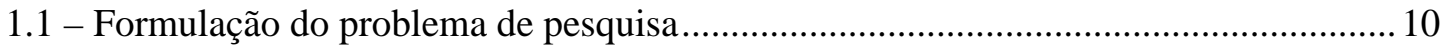

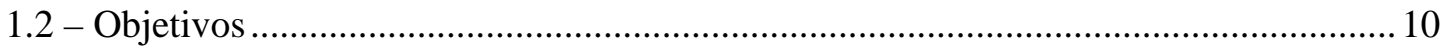

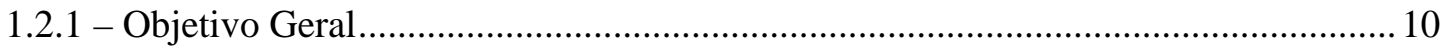

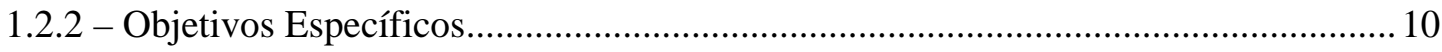

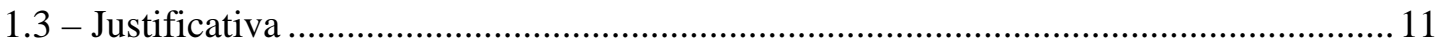

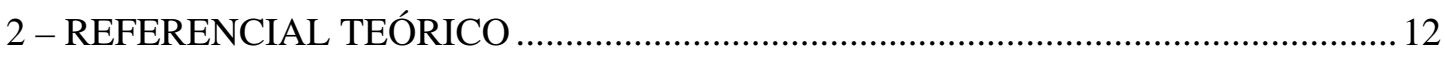

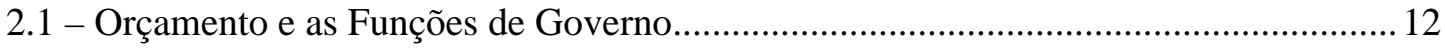

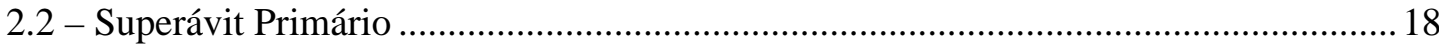

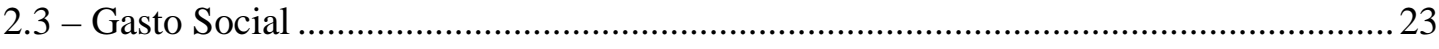

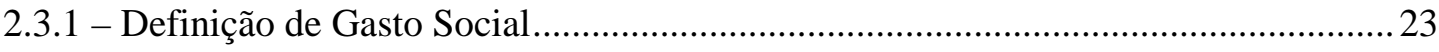

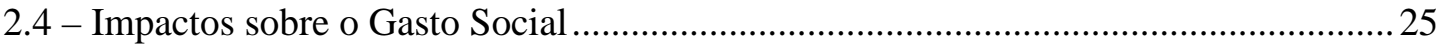

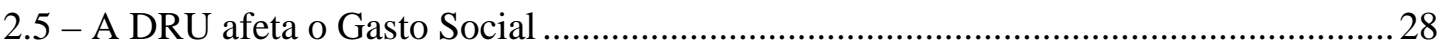

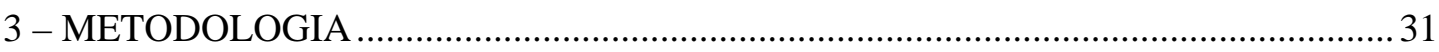

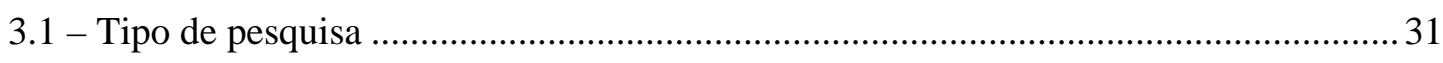

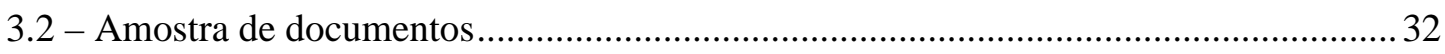

3.3 - Procedimentos da Coleta de Dados.......................................................................... 33

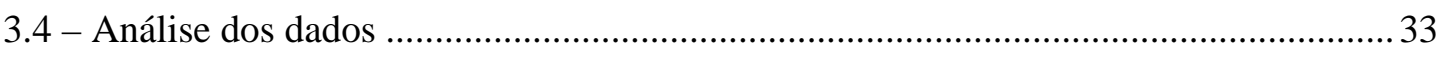

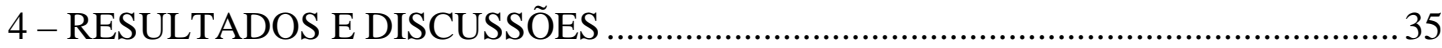

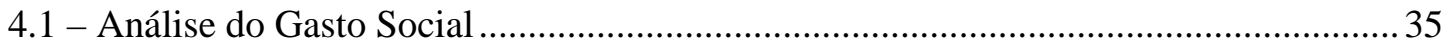

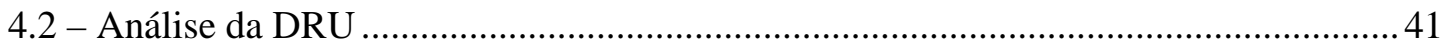

4.3 - Análise do Superávit Primário …………………………………………………......... 42

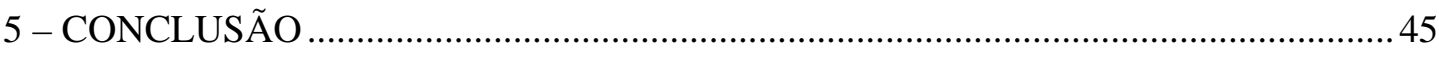

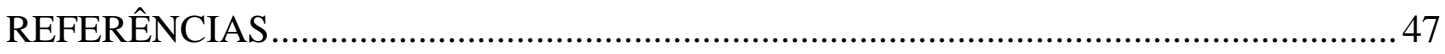

ANEXO 


\section{1 - INTRODUÇÃO}

O governo é uma entidade que coleta recursos através de impostos cobrados da população para transferir esses recursos sob a forma de bens e serviços para outra parte da população.

Do nascimento à morte, nossas vidas são afetadas de inúmeras maneiras pelas atividades do governo. Virtualmente todos nós, em algum momento de nossas vidas, recebemos dinheiro do governo. Como diz Stiglitz, o gasto do governo afeta uma gama diversa de atividades, algumas das quais, em algum momento, provavelmente teve, tem ou terá algo a ver com a vida de cada um de nós (GIAMBIAGI; ALÉM, 2001, p. 52-53).

Algumas funções são típicas de governo e objetivam o atendimento da necessidade e bem-estar da coletividade. As políticas sociais se enquadram numa dessas funções que podem ser assumidas pelo Governo de modo total ou parcial, através de parcerias privadas, e objetivam tão somente o atendimento de necessidades fundamentais. O que se define como necessidade fundamental varia de país a país e está associada ao processo histórico vivenciado pelos indivíduos, bem como da saúde da economia e do amadurecimento da sociedade enquanto conhecimento de seus direitos.

Um fator de influência é a chamada lei de oferta e demanda, também conhecida como lei de mercado, que nem sempre consegue atender as necessidades da população, precisando, em determinados momentos, da intervenção do Governo para atuar como regulador deste mercado.

A demanda por serviços públicos tem crescido muito nas últimas décadas e está em parte ligada à urbanização.

O aumento de grau de escolaridade, do nível de renda e conscientização dos direitos fundamentais demandam mais recursos orçamentários para o atendimento da necessidade desta sociedade, que possui maior consciência política dos seus direitos e do que pode ou deve reinvindicar.

Observa-se que há uma necessidade crescente de demanda associada a políticas sociais e o governo não tem conseguido atendê-la. Pretende-se estudar o assunto e os motivos desta falha do governo. 


\section{1 - Formulação do problema de pesquisa}

A preocupação do Governo com o cumprimento da meta de superávit primário gera reflexão sobre quais gastos são reduzidos para o alcance deste indicador. Diante do exposto, surge o seguinte questionamento: há redução do gasto social em virtude da meta de Superávit Primário?

\section{2 - Objetivos}

\subsection{1 - Objetivo Geral}

O gasto social é tão importante quanto o pagamento da dívida, mas até que ponto a balança está pendendo mais para um dos lados.

O objetivo deste trabalho é demonstrar se houve redução do gasto social em cumprimento à meta de Superávit Primário.

\subsection{2 - Objetivos Específicos}

Seguem os objetivos específicos pretendidos com esta monografia:

i Definir o que é gasto social;

ii Relatar a metodologia de formação do superávit primário;

iii Demonstrar a realização do superávit primário em números absolutos e em percentual sobre o PIB;

iv Demonstrar com dados estatísticos os gastos sociais e que áreas vêm sendo afetadas;

v Efetuar análise do efeito do superávit primário sob o gasto social;

vi Analisar se a DRU está afetando o gasto social; 


\section{3 - Justificativa}

O Governo tem perseguido fortemente o cumprimento da meta fiscal de Superávit Primário para pagar os juros da dívida, com intuito de controlá-la e sinalizar ao mercado que o Brasil é um país confiável. Deste modo, evitam-se fortes oscilações na economia provocadas por especulações e permite obter um crescimento econômico sustentável.

Em decorrência da política fiscal estabelecida pelo Governo, tem-se observado, nos últimos anos, uma forte perseguição pelo cumprimento da meta de superávit primário, inclusive com o estabelecimento de metas superiores ao que foi estabelecido inicialmente pelo Fundo Monetário Internacional (FMI), quando do acordo firmado no ano de 1999, em $3,1 \%$.

A economia feita pelo Governo, destinada ao pagamento de juros da dívida, nos faz refletir sobre o quanto ela custa. Se por um lado precisa-se pagar a dívida, por outro há uma necessidade acentuada e crescente de investimento.

O valor que sobra para investir está cada vez mais reduzido. $\mathrm{O}$ excesso de vinculação de recurso provocou uma forte rigidez orçamentária, dificultando em muito a ação discricionária dos gestores públicos e a eleição de prioridade em investimento.

Quando o Governo aumenta a meta de superávit primário, e não obtêm os recursos necessários ao cumprimento desta meta através da redução de seus gastos, afeta os recursos destinados a investimentos, o que impacta nas obras de infra-estrutura e nos gastos sociais.

Apesar da polêmica em torno do superávit primário brasileiro, é inegável a necessidade de pagamento da dívida, e não se encontra quem defenda uma política fiscal de déficit primário para se chegar ao crescimento econômico.

Entretanto, muitos gastos sociais têm suas fontes de recursos vinculadas a arrecadações de tributos e o que se tem observado nos últimos anos é um crescente recorde de arrecadação divulgado pela Secretaria da Receita Federal do Brasil - SRF. O que nos faz refletir que alguma política social está sendo mais afetada que outra, necessitando de maior esclarecimento ou indicação do ponto crítico, pois os recursos orçamentários e suas despesas são afetados por fatores econômicos e fiscais. 


\section{2 - REFERENCIAL TEÓRICO}

Para estudar o assunto o texto está organizado da seguinte forma: além da introdução e justificativa, em mais 5 seções e um anexo. Na seção 2.1, são apresentadas as funções orçamentárias e suas implicações devido ao excesso de vinculação de recursos. $\mathrm{Na}$ seção 2.2, são mencionadas definições para explicar o significado do superávit primário, termo altamente utilizado atualmente, e descreve-se sua importância e as discussões envolvidas sobre o assunto. Na seção 2.3, são apresentadas algumas definições utilizadas entre política social e áreas de atuação social do gasto federal, e são descritos os impactos da política fiscal sobre o gasto social. Na seção 2.4, é discutido como a DRU vem sendo utilizada e os impactos que os gastos sociais vêm sofrendo em sua decorrência.

\section{1 - Orçamento e as Funções de Governo}

Desde a Constituição Federal de 1988 o orçamento brasileiro passou por um processo de mudança. Visando garantir a aplicação de recursos em determinadas áreas foram estabelecidas destinações específicas para algumas receitas do Governo Federal. Este processo, que inicialmente ocorreu com a promulgação da constituição de 88 e com a adoção de novas legislações posteriores, acabou por reduzir o grau de discricionariedade do gestor público na alocação de recursos.

Para se ter uma clara noção da elevação do grau de vinculação dos recursos que foram promovidos ao longo dos anos, tem-se a Figura 1 elaborada pela Secretaria de Orçamento Federal - SOF. 


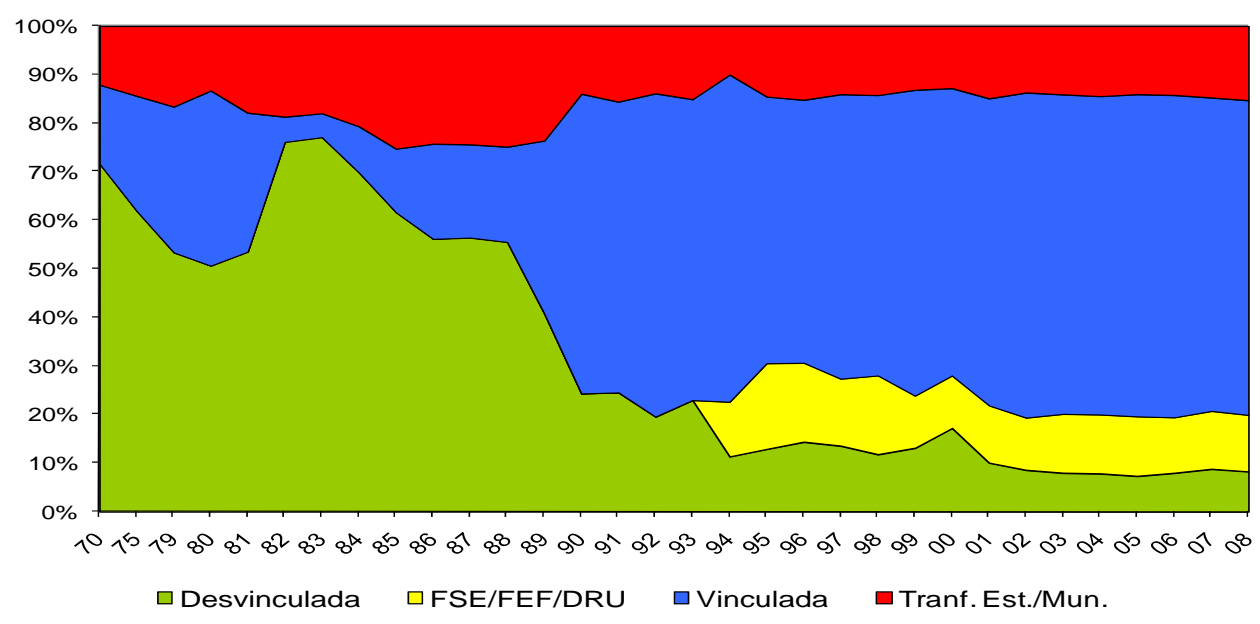

Figura 1 - Composição das receitas orçamentárias

Fonte: Secreataria de Orçamento Federal - SOF (2008)

A redução do grau de discricionariedade do Governo Federal é demonstrada na Figura 1 pelo recurso "desvinculada".

Somadas as vinculações e transferências constitucionais, ainda existem os gastos obrigatórios e essenciais. Os gastos obrigatórios em sua boa medida são incomprimíveis como os gastos com pessoal e previdência, e os gastos essenciais são imprescindíveis para o funcionamento da estrutura do Governo como água, luz, telefone. Com isto, o orçamento tornou-se bastante rígido, dificultando a alocação de recursos e a eleição de prioridades.

\begin{tabular}{|c|c|c|c|c|c|c|c|c|c|c|}
\hline \multirow{2}{*}{ Discriminação } & \multicolumn{2}{|c|}{ Exec. 2004 } & \multicolumn{2}{c|}{ Exec. 2005 } & \multicolumn{2}{c|}{ Exerc. 2006 } & \multicolumn{2}{c|}{ Exerc. 2007 } & \multicolumn{2}{c|}{ Exerc. 2008 } \\
\cline { 2 - 11 } & Valor & $\%$ & Valor & $\%$ & Valor & $\%$ & Valor & $\%$ & Valor & $\%$ \\
\hline Desp. Primárias & 376.6 & $100.0 \%$ & 447.4 & $100.0 \%$ & 501.3 & $100.0 \%$ & 574.6 & $100.0 \%$ & 649.9 & $100.0 \%$ \\
\hline Obrigatórias & 306.8 & $81.5 \%$ & 361.1 & $80.7 \%$ & 405.0 & $80.8 \%$ & 450.7 & $78.4 \%$ & 517.0 & $79.6 \%$ \\
\hline Discricionárias & 69.8 & $18.5 \%$ & 86.3 & $19.3 \%$ & 96.3 & $19.2 \%$ & 123.9 & $21.6 \%$ & 132.9 & $20.4 \%$ \\
\hline
\end{tabular}

Tabela 1 - Discriminação das despesas primárias governo central Fonte: Secretaria de Orçamento Federal - SOF

Apesar de percentualmente variável, a execução de despesas discricionárias tem cada vez mais seu espaço reduzido, conforme demonstrado na Tabela 1. Cabe ressaltar, que os gastos essenciais se encontram diluídos nas despesas discricionárias. Isto prejudica a execução de obras de investimento em infra-estrutura, essenciais ao crescimento da economia e fonte geradora de novos empregos. 


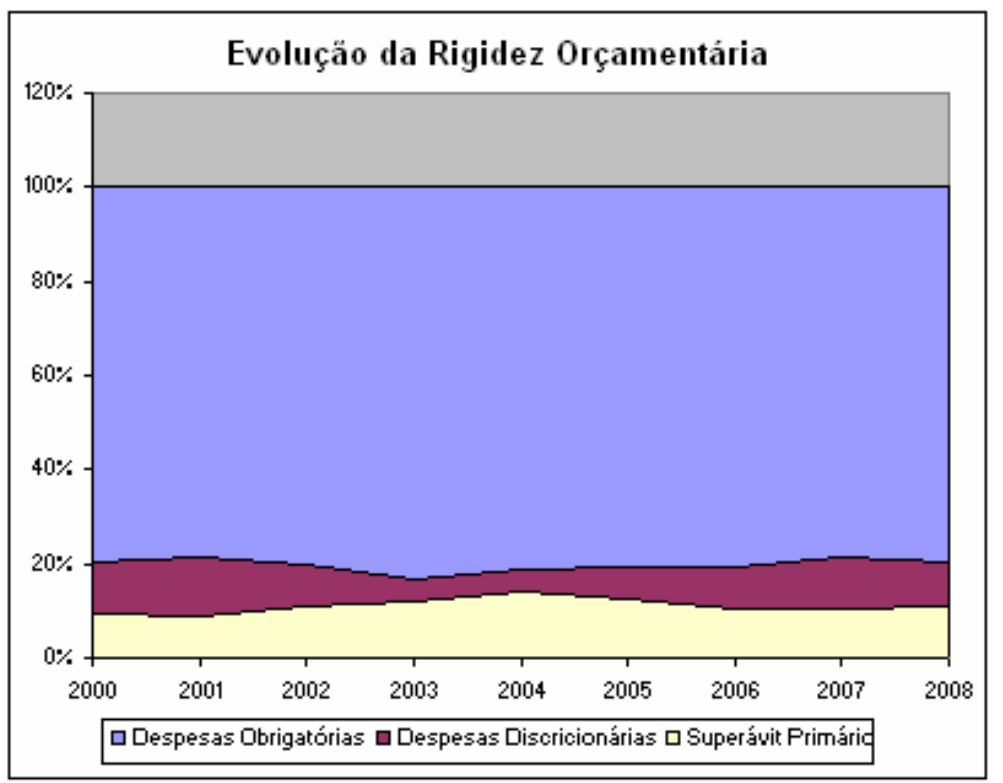

Gráfico 1 - Evolução da rigidez orçamentária

Fonte: Secretaria de Orçamento Federal - SOF e Banco Central do Brasil - BACEN

Esse montante avultoso de despesas obrigatórias demonstrado no Gráfico 1 dificulta

... sobremaneira o gerenciamento e a condução de uma política fiscal voltada para o enfrentamento de problemas conjunturais. Ademais, a política de manutenção de determinado patamar de superávit primário reduz ainda mais o nível de despesas discricionárias do Governo Central (SOF, 2003, p. 12).

A rigidez orçamentária atingiu um grau tão elevado que a União passou a se endividar no mercado para pagamento de despesas obrigatórias quando dispunha de recursos sobrando em outras fontes. Foi necessário fazer uma legislação no sentido contrário para desvincular parte dos recursos que estavam vinculados, sendo então criada a Desvinculação de Recursos da União (DRU).

A DRU, de acordo com informação divulgada no site do Ministério do Planejamento, Orçamento e Gestão:

Objetiva tão somente dar uma maior flexibilidade à alocação dos recursos públicos e não significa elevação das receitas disponíveis para o governo federal. Além disso, não afeta as transferências constitucionais para Estados e Municípios, cuja principal fonte de receita é o Imposto sobre Produtos Industrializados e o Imposto de Renda, uma vez que a desvinculação é feita após os cálculos das transferências constitucionais para estados e municípios.

Segundo o mesmo site, as finalidades da DRU são:

1. Permitir a alocação mais adequada de recursos orçamentários; 2. Não permitir que determinados itens de despesas fiquem com excesso de recursos vinculados, ao mesmo tempo em que outras áreas apresentam carência de recursos; e 3. Permitir o financiamento de despesas incomprimíveis sem endividamento adicional da União. 
A DRU é um mecanismo que permite o Governo gastar livremente $20 \%$ (vinte por cento) da arrecadação da União de impostos, contribuições sociais e de intervenção no domínio econômico (Brasil, EC nº 56, art. 1º). Criada em 1994, através de um projeto de emenda à Constituição, autorizava, provisoriamente, a desvinculação de $20 \%$ de todos os impostos e contribuições federais que formava uma fonte de recursos livre de carimbos, denominada inicialmente Fundo Social de Emergência - FSE, posteriormente denominado Fundo de Estabilização Fiscal - FEF, que vigorou até 31 de dezembro de 1999. A partir do ano 2000 foi reformulada e passou a se chamar Desvinculação de Recursos da União (DRU) tendo sua prorrogação aprovada pelo Congresso Nacional através de Proposta de Emenda à Constituição (PEC) (SOF, 2003, p. 14-17). A última aprovação ocorreu em 2008 prorrogando sua vigência até 2011.

A LRF ao determinar que as receitas vinculadas sejam utilizadas exclusivamente para atender o objeto de sua vinculação, ainda que em exercício diverso daquele em que ocorrer o ingresso, intensificou o problema de vinculações orçamentárias. Dessa maneira, tem-se verificado o crescimento, durante os últimos exercícios, do montante de receitas vinculadas que não podem ser destinadas ao pagamento de gastos cuja finalidade seja diferente da definida, nem ao pagamento de juros, encargos e amortização da Dívida Pública do Governo Central (SOF, 2003, p. 21).

Tendo em vista o que foi exposto, faz-se uma reflexão com relação às funções do Governo e do quanto à vinculação tem afetado o papel do Estado.

Musgrave (1941, p. 3-17 apud GIACOMONI, 2003, p. 38) "propôs uma classificação das funções econômicas do Estado, que se tornaram clássicas no gênero. Denominadas as 'funções fiscais', o autor as considera também como as próprias 'funções do orçamento', principal instrumento de ação estatal na economia”.

São três as funções:
a) alocativa;
b) distributiva; e
c) estabilizadora.

Função Alocativa - função de promover ajustamentos na alocação de recursos. Estabelece o fornecimento de bens públicos à população, "tem o objetivo de alocar os recursos quando não seja possível pelas condições de mercado, a determinação de preços de bens e serviços de forma a assegurar uma maior eficiência na utilização dos recursos 
disponíveis na economia" (REZENDE, 2001, p. 17).

A vinculação de recursos afeta essa função de duas formas. Afeta de maneira positiva, pois garante a alocação de recursos para as funções primordiais do Estado, mas também afeta de maneira negativa, pois a rigidez orçamentária dificulta a execução da política fiscal e a alocação de recursos para investimento.

Função Distributiva - função de promover ajustamentos na distribuição de renda, ou seja, realiza ajustes na distribuição de renda, tornando-a mais justa. Esta função tem importância fundamental para o crescimento equilibrado do País. Por intermédio dela, o Governo deve combater os desequilíbrios regionais e sociais, promovendo o desenvolvimento das regiões e classes menos favorecidas.

Para Giambiagi e Além, a função distributiva ocorre da seguinte forma:

\footnotetext{
Em primeiro lugar, através do esquema de transferências o governo pode promover uma redistribuição direta da renda, tributando em maior medida os indivíduos pertencentes às camadas de renda mais alta, e subsidiando os indivíduos de baixa renda.

Em segundo lugar, os recursos captados pela tributação dos indivíduos de renda mais alta podem ser utilizados para financiamento de programas voltados para a parcela da população de baixa renda, como o de construção de moradias populares (GIAMBIAGI; ALÉM, 2001, p. 33).
}

Aqui, a vinculação de recursos afeta essa função de forma positiva, pois garante que estados e municípios recebam recursos provindos da União através de transferências constituicionais obrigatórias. O percentual de transferência tem por base a região de localização do ente, efetuando a distribuição dos recursos de forma progressiva, onde o ônus tributário recai sobre o estado ou município com maiores arrecadações, visto que promove a transferência de parcela dos recursos arrecadados em áreas mais desenvolvidas para áreas menos desenvolvidas do País, constituindo um importante instrumento de redistribuição da renda nacional.

A título de conhecimento seguem os percentuais de transferências constitucionais obrigatórios. O Fundo de Participação dos Estados - FPE: 85\% dos recursos (IRPF e IPI) são destinados aos estados das regiões Norte $(25,37 \%)$, Nordeste $(52,46 \%)$, Centro- Oeste $(7,17 \%)$, Sul (6,52\%) e Sudeste (8,48\%). O Fundo de Participação dos Municípios - FPM: $22,5 \%$ dos recursos (IRPF e IPI) são destinados aos municípios observados os coeficientes individuais de participação que são fixados por Decisão Normativa específica do Tribunal de Contas da União - TCU. Os percentuais do FPM destinados aos Municípios de cada Estado foram fixados com base na Lei Complementar $n^{\circ}$ 62/1989 e tiveram como base a faixa de habitantes. 
Função Estabilizadora - função de manter a estabilidade econômica. Procura melhorar o nível de emprego, estabilizar os preços, equilibrar a balança de pagamentos e taxas de câmbio e obter a estabilidade do crescimento econômico, visando o desenvolvimento sustentável do país.

De acordo com Giambiagi e Além,

O funcionamento do sistema de mercado não é por si só, capaz de assegurar altos níveis de emprego, estabilidade dos preços e altas taxas de crescimento econômico. Sendo assim, a intervenção do governo pode ser importante no sentido de proteger a economia de flutuações bruscas, caracterizadas por alto nível de desemprego e / ou alto nível de inflação. Para isso, os principais instrumentos macroeconômicos à disposição do governo são a política fiscal e monetária (GIAMBIAGI; ALÉM, 2001, p. 35).

A vinculação não afeta diretamente esta função, mas ela é realizada pelo Estado quando destina percentual de recursos do orçamento para formação do superávit primário, economia que o Governo faz destinada ao pagamento da dívida, o que também pode ser visto como uma forma de vinculação.

Por outro lado, a rigidez orçamentária criada pelo excesso de vinculação de recursos afeta negativamente esta função, pois dificulta ao governo a tomada de decisão e a realocação de recursos em momentos de crise econômica.

Salienta-se que a política fiscal e econômica devem ser utilizadas como uma ferramenta para diminuir os desequilíbrios do mercado e melhorar as taxas de crescimento econômico do país. Entretanto, alguma medida precisa ser tomada para flexibilizar a rigidez orçamentária, pois ela não tem afetado somente a discricionariedade dos gestores públicos, tendo refletido também na alocação de recursos destinado as políticas públicas, impactando diretamente nos gastos sociais.

O governo utiliza a função estabilizadora conjugando política fiscal e monetária para obtenção da estabilidade econômica. Essa questão é explicada por Giambiagi e Além (2001), da seguinte forma:

A política fiscal pode se manifestar diretamente, através da variação dos gastos públicos em consumo e investimento, ou indiretamente, pela redução das alíquotas de impostos, que eleva a renda disponível do setor privado.

No caso da existência de um alto nível de inflação, por sua vez, o governo pode agir de forma inversa ao caso anterior, através da diminuição dos seus gastos e do aumento das alíquotas dos impostos.

Dependendo da situação, o governo pode preferir agir através da política monetária. Em casos de recessão ou desaceleração do crescimento econômico, o governo pode promover uma redução das taxas de juros, estimulando desta forma o aumento dos investimentos. Alternativamente, em uma situação de excesso de demanda com impactos inflacionários, o governo pode aumentar as taxas de juros, reduzindo, desta maneira, a demanda agregada da economia (GIAMBIAGI; ALÉM, 2001, p. 35). 
É importante ressaltar, que desde a implantação da LRF, lei complementar no. 101 de 2000, foi possível retomar o controle dos gastos públicos. Entre as medidas adotadas pela lei está à imposição de limites na aplicação de recursos públicos e para o endividamento. A história econômica do país tem nos mostrado que a aplicação isolada da política monetária é insuficiente e ineficaz, sendo necessária a conjugação com a política fiscal. A LRF possibilitou a adoção de medidas fiscais para o controle do endividamento interno, principal dívida do País, e o controle dos gastos públicos. Desta forma, o governo passa a poder contar com a política fiscal para realização de sua função, pois se a inflação está alta e o governo continua injetando uma grande quantidade de recursos no mercado haverá uma elevação da liquidez e conseqüente descontrole da economia.

\section{2 - Superávit Primário}

É a economia que o Governo faz destinada ao pagamento de juros da dívida e quitação de parte das dívidas. Para entender a importância deste indicador faz-se necessário compreender o significado de superávit e déficit. Falando numa linguagem simplificada, o superávit ocorre quando as receitas são maiores que as despesas. Por outro lado, o déficit ocorre quando as despesas são maiores que as receitas. Fazendo uma analogia com a vida doméstica, significa pagar as contas com seu salário e ainda reservar um dinheiro para colocar na poupança. Esse dinheiro da poupança ou reserva é o que se denomina superávit. Caso seja necessário fazer um empréstimo para pagar as contas, pois o salário não foi suficiente, o valor do empréstimo é chamado de déficit.

Descreve-se a seguir o cálculo simplicado que é feito para obtenção do superávit primário e uma descrição das receitas e despesas envolvidas.

Receitas primárias (I) - "são receitas que o governo obtém sem ampliação de sua dívida ou redução de seus ativos", ou seja, obtenção de receitas que não acarretem nem endividamento, nem redução de seu patrimônio (ALBUQUERQUE; MEDEIROS; FEIJÓ, 2008, p. 72).

Conceito segundo a Lei de Diretrizes Orçamentárias - LDO:

As receitas primárias referem-se predominantemente a receitas correntes, e é composto daquelas que advêm dos tributos, das contribuições sociais, das 
concessões, dos dividendos recebidos pela União, da cota-parte das compensações financeiras, das decorrentes do próprio esforço de arrecadação das unidades orçamentárias (fontes 50, excluída a arrecadada pelo Fundo de Compensação das Variações Salariais - FCVS), das provenientes de doações e convênios e outras também consideradas primárias (BRASIL, 2005, p. 25).

Despesas primárias (II) - despesas consideradas para o cálculo do resultado primário segundo critérios da LRF. Subdivide-se, para efeito de demonstração, em obrigatórias e discricionárias, as que estão sujeitas a contingenciamento. Conceito:

São todas as despesas, deduzidas aquelas com:

- $\quad$ amortização, juros e outros encargos da dívida interna e externa;

- $\quad$ aquisição de títulos de capital já integralizado;

- concessão de empréstimos com retorno garantido; e

- transferências entre as entidades que compõem o ente federativo, de forma a evitar dupla contagem (ALBUQUERQUE; MEDEIROS; FEIJÓ, 2008, p. 72).

Resultado Primário (III) $=$ (I) - (II) - Referem-se ao resultado das Receitas Primárias (RP) menos as Despesas Primárias (DP), e “indica se os níveis de gastos orçamentários dos entes federativos são compatíveis com a sua arrecadação", ou seja, se as Receitas Primárias são capazes de suportar as Despesas Primárias (ALBUQUERQUE; MEDEIROS; FEIJÓ, 2008, p. 72).

Superávit Primário (III > 0) - ocorre quando as receitas primárias são maiores que as despesas primárias, resultando em saldo positivo no Resultado Primário.

Déficit Primário (III < 0) - ocorre quando as receitas primárias são menores que as despesas primárias, resultando em saldo negativo no Resultado Primário.

Informações mais detalhadas de como proceder ao cálculo do superávit primário podem ser obtidas consultando o Anexo - Metodologia de cálculo do superávit primário elaborado pela Secretaria do Tesouro Nacional - STN.

Resultado Nominal (V) $=$ (I)-(II)-(IV) - referem-se ao resultado das Receitas Primárias (RP) menos as Despesas Primárias (DP) e Dívida Pública. Indica que os níveis de gastos orçamentários dos entes federativos não são compatíveis com sua arrecadação, ou seja, as receitas primárias não são capazes de suportar as despesas primárias e o pagamento da dívida pública.

Dívida Pública (IV) - é a soma de tudo aquilo que os órgãos do Estado brasileiro devem, incluindo o governo federal, estados, municípios e empresas estatais.

Segundo o DIEESE (2003, p. 2), a dívida é contraída pelos entes federativos junto a entidades ou pessoas da sociedade para financiar parte de seus gastos, que não são cobertos com a arrecadação de impostos, ou alcançar objetivos de gestão econômica, tais como 
controlar o nível de atividade econômica, o crédito e o consumo ou, ainda, para captar dólares no exterior. O governo tem três formas de financiar seus gastos: arrecadar impostos, emitir moeda ou vender títulos (papéis) da dívida pública com promessa de resgate futuro acrescido de juros. A emissão de moeda é uma forma utilizada pelos governos para financiar parte de seus gastos, mas deve ser usada com cautela, uma vez que pode se transformar em inflação, caso a economia esteja operando próxima ao pleno emprego dos fatores de produção e se essa emissão de moeda não guardar alguma relação com o crescimento da oferta de bens e serviços.

Mas, o que isso significa?

Como dito anteriormente, o superávit primário é a economia que o Governo faz destinada ao pagamento de juros da dívida e quitação de parte das dívidas. O esforço econômico é um trabalho conjunto da União, dos estados, dos municípios e das empresas estatais, que conseguem economizar, sem considerar os gastos com os juros da dívida.

A meta de superávit primário é estabelecida em percentual sobre o Produto Interno Bruto - PIB, que é um dos mais importantes indicadores de uma economia e representa a soma, em valores monetários, de todos os bens e serviços produzidos no País em determinado período. Ele revela o valor de toda riqueza gerada no país.

A história do Brasil tem décadas de governantes que gastavam mais que arrecadavam, gerando seguidos déficits primários, cujo prejuízo nas contas teve de ser coberto com empréstimos, gerando endividamento do Estado.

A adoção da prática de superávit primário se deu por orientação do Fundo Monetário Internacional - FMI, a partir de 1994, com o objetivo de fazer com que o País transmitisse aos investidores a confiança de que o gorveno honrará seus compromissos com o pagamento dos juros da dívida.

Nos últimos anos, o governo brasileiro tem mantido uma política de superávits primários na faixa de $3,6 \%$ a 4,8\%, decorrente da política fiscal adotada. Mesmo com tanto esforço, o superávit primário paga somente parte dos juros da dívida, sendo necessário financiar o restante, o que eleva o déficit nominal e aumenta o custo da rolagem da dívida. 


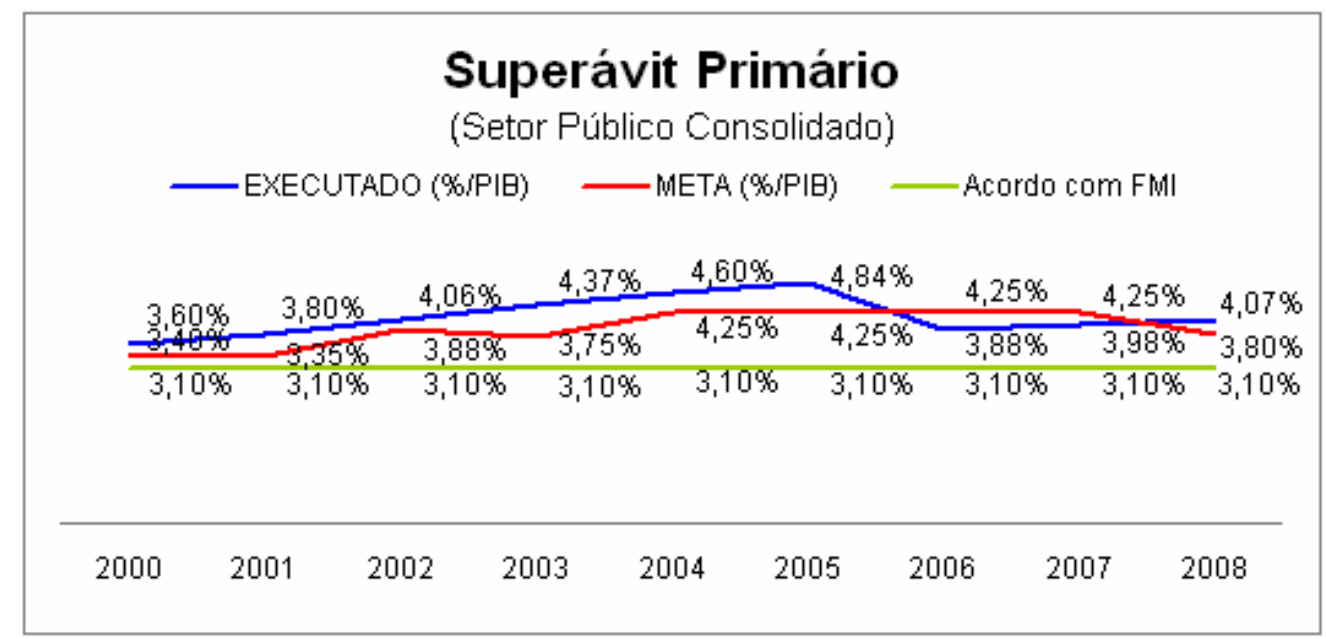

Gráfico 2 - Execução e meta do superávit primário

Fonte: Banco Central - BACEN e Secretaria de Orçamento Federal - SOF

* Setor Público Consolidado (União, Estados, Municípios e Estatais)

Essa prática de manutenção da meta de superávit primário gera muitas discussões entre os especialistas.

Para Ferreira, Siqueira e Silva (2006, p. 11), existem duas correntes de pensamento. Uma corrente é favorável à manutenção do superávit primário como forma de política fiscal, objetivando o alcance do déficit nominal zero, e a outra corrente é contrária à prática do superávit primário por comprometer os investimentos públicos em infra-estrutura e em políticas sociais.

Munhoz (2005) chama atenção para o significado do aumento de superávit primário, que significa maior parcela da arrecadação de impostos que é desviada para pagamento de juros, ou seja, maior superávit significa menos gasto com serviços de saúde, educação, transportes, habitação, modernização de vias públicas nos grandes centros, segurança pública, conservação de estradas, etc. Ele declara ainda, que o superávit primário empobrece mais o país sendo sustentado por uma carga tributária absurda, que se elevou de 25,3\% em 1993 para algo em torno de 38\% em 2005.

Entretanto, como concluem Ferreira, Siqueira e Silva (2006, p. 18), apesar das divergências com relação ao superávit primário, nenhuma das correntes de pensamentos defende uma política fiscal de déficit orçamentário para se obter o crescimento econômico, e cita como alguns países trabalham:

Países como Estados Unidos e alguns da União Européia trabalham com déficit orçamentário, baixas taxas de juros, tributos estabilizados e ainda protegem suas indústrias de produtos importados, tudo com a finalidade de incentivar o crescimento econômico. Existem ainda países em desenvolvimento comparados ao Brasil, como Malásia, Índia e China, que possuem mecanismos de controle de 
fluxos de capitais. Isto permite a eles elaborarem uma política econômica soberana sem uma meta de superávit primário que prejudique o crescimento econômico como a do Brasil (FERREIRA; SIQUEIRA; SILVA, 2006, p. 18).

Como citado anteriormente, a discussão diverge entre os especialistas, sendo questionado o fato de a dívida ser pagável ou não. Entretanto, um estudo efetuado pelo BACEN com relação ao pagamento da dívida com utilização do superávit primário, divulgado através de nota técnica n. 25 e reafirmada na nota técnica n. 39 de julho 2003 , concluiu que

Sob hipóteses razoáveis e mesmo conservadoras, a relação dívida/PIB deve começar a declinar ao longo dos próximos anos. Esse resultado é válido mesmo se houver resultados negativos dos determinantes relevantes - taxa de juros real, crescimento do PIB, taxa de câmbio real e passivos contingentes. A condiçãochave necessária é a manutenção de superávit primário de $3,75 \%$ do PIB (GOLDFAJN, p. 26, 2002).

Giambiagi (2005) defendeu em seu artigo a idéia de elevação da meta de superávit primário para $5 \%$ do PIB para 2006, e apresenta quatro fortes razões:

- A contribuição permitiria o relaxamento gradual da política monetária, permitindo juros reais menores;

- Um primário na ordem de 5\%, mesmo que em condições adversas permitiria que a relação dívida/PIB mantivesse a trajetória de queda;

- Com premissas realistas de redução gradual da taxa de juros nos próximos anos, permitiria ao país atingir o famoso déficit zero em 2008;

- Não existe melhor forma de blindar a economia.

Para Meirelles (2008), presidente do Banco Central (BC), elevar meta de superávit primário "é positivo". Ele ressalta o fato de não haver dúvida de que o aumento do superávit tem um componente positivo porque reduz a necessidade de captação de recursos do Tesouro e, em consequiência, a pressão sobre o mercado de taxa de juros.

Conclui-se então que o esforço do governo é válido, pois se conseguirá chegar no patamar desejado de déficit nominal zero, considerando a relação dívida/PIB. Segundo projeções estatísticas demonstrada na Figura 2, caso o governo mantenha a meta de superávit em torno de 3,8\%, a dívida chegará a esse marco em 2011. 


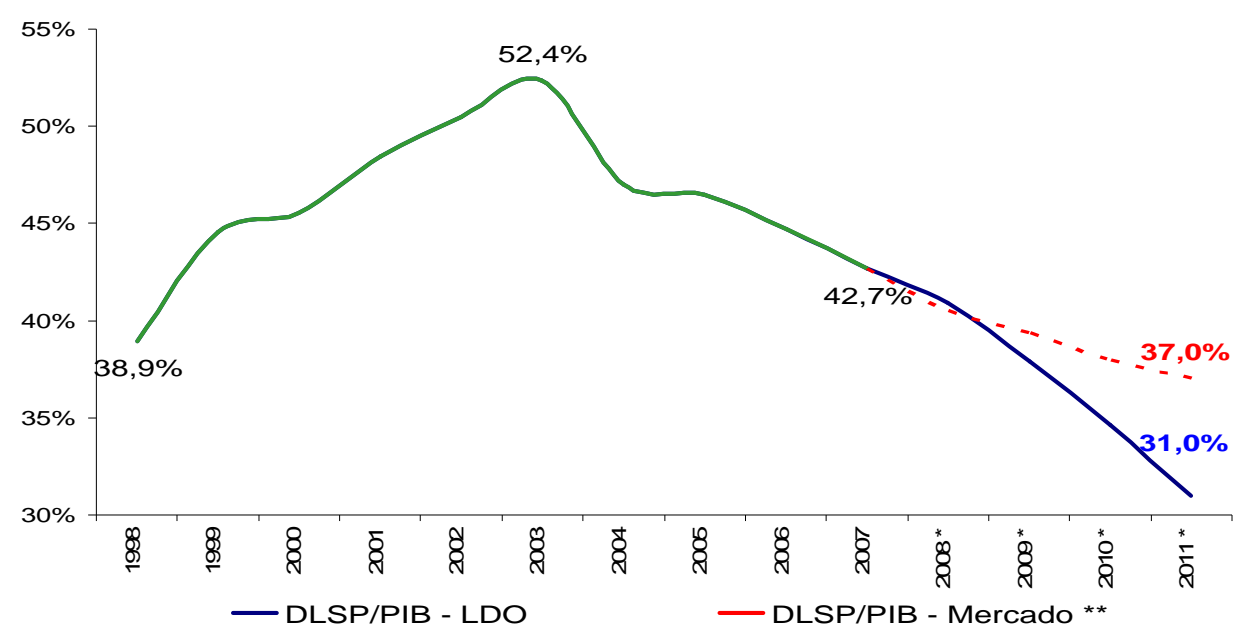

Figura 2 - Dívida líquida do setor público/PIB

Fonte: Até 2007, Banco Central. A partir de 2008, PLDO 2009 e FOCUS de 08/08/2008.

Cabe ressaltar, que o Governo tem utilizado o superávit primário como um dos principais instrumentos de política fiscal, com o intuito de alcançar o equilíbrio das contas públicas e, também, possibilitar que o país possa resistir com mais força às especulações do mercado.

\section{3 - Gasto Social}

\subsection{1 - Definição de Gasto Social}

A definição de gasto social é variada e divergente entre os especialistas, porém, há um consenso entre eles de que as áreas sociais são educação, cultura, saúde, saneamento e meio ambiente, previdência social, assistência social, segurança pública e habitação.

Santos (1987 apud CASTRO, 2003, p. 8) descreve Política Social como um "termo largamente usado, mas que não tem uma definição precisa. O sentido em que é usado em qualquer contexto particular é em vasta matéria de conveniência ou de convenção (...) e nem uma, nem outra, explicará de que trata realmente a matéria”. Outra concepção também citada em Santos, dada pelo investigador Ramesh Mishra, admite que "política social pode 
ser definida em termos relativamente estreitos ou largos. Nada existe de intrinsecamente certo ou errado em tais definições, na medida em que sejam apropriadas à tarefa em vista".

O conceito defendido por Fernandes (1998, p. 7-9) define que gasto público social compreende os recursos financeiros brutos empregados pelo setor público no atendimento de demandas sociais e que corresponde ao custo de bens e serviços. A autora acrescenta ainda que, "a maioria dos estudos define o gasto social por meio da enumeração dos setores considerados de interesse social e está definição incorpora um forte componente de juízo de valor, o que torna a enumeração diferenciada entre os estudos".

Cardoso e Castro (2006, p. 147) entendem como política social um conjunto de programas e ações do Estado, objetivando o atendimento dos direitos e necessidades fundamentais que afetam as condições básicas de vida da população. Essas necessidades são divergentes entre as sociedades, pois são fatores influenciados pelo processo histórico de cada uma. Os autores ainda descrevem o sentido para a política social que é a busca pela segurança do indivíduo em determinadas situações de dependência e o atendimento de demandas por maior igualdade, e cita alguns exemplos do que seria a dependência 'momentânea' como: “incapacidade de ganhar a vida no mundo do trabalho; posições vulneráveis dentro do ciclo de vida do ser humano (crianças e idosos, por exemplo); situações de risco, como em casos de acidentes que causam invalidez".

Segundo a classificação proposta pela Organização das Nações Unidas, as despesas com financiamento público de serviços sociais básicos seriam: educação, saúde, segurança social, habitação, esporte e outras características semelhantes.

No caso do Brasil, a Constituição Federal - CF de 1988 no capítulo II - dos Direitos Sociais, alterado pela Emenda Constitucional n. 26/2000, assegura os direitos sociais a educação, a saúde, o trabalho, os direitos trabalhistas adquiridos, a moradia, o lazer, a segurança, a previdência social, a proteção à maternidade e à infância, e a assistência aos desamparados (BRASIL, 2006).

Há uma série de leis ordinárias que vieram complementar o estabelecido na $\mathrm{CF}$ e que são reconhecidas como direitos sociais por melhorar as condições de vida da população. Estão relacionadas em programas e ações do Governo, complementando o leque de políticas sociais ofertadas pelo país, como: cultura, habitação e urbanismo e saneamento básico, proteção ao meio ambiente, organização agrária e ciência e tecnologia.

Em suma, a política social reflete a vontade do povo e suas necessidades básicas. Elas variam de acordo com a sociedade, pela influência de seu histórico, e a saúde da 
economia, e está diretamente ligada à segurança e ao bem-estar da coletividade.

Cabe ressaltar que o conceito utilizado neste trabalho é o definido na Constituição Federal juntamente com seus complementos, efetuados através de Emendas Constitucionais e leis ordinárias, pois representa a vontade do povo brasileiro e define os direitos e garantias fundamentais: educação, saúde, trabalho, direitos trabalhistas, moradia, lazer, segurança, previdência social, proteção à maternidade e à infância, assistência aos desamparados, cultura, habitação, urbanismo, saneamento básico, meio ambiente, organização agrária e ciência e tecnologia.

\section{4 - Impactos sobre o Gasto Social}

A obtenção de superávit primário pode ser realizada de três maneiras: 1) através de redução do gasto administrativo da máquina pública ou 2) através de aumento da arrecadação de impostos e conseqüentemente aumento da carga tributária ou 3) combinação dos dois citados inicialmente.

O que se observou é que a formação do superávit primário ocorreu basicamente com o aumento da carga tributária, disponível em âmbito federal, através de arrecadação de impostos, especialmente, das contribuições sociais. "Esse movimento esteve associado ao fato de as contribuições sociais serem tributos não repassáveis para estados e municípios, e também devido à possibilidade de desvincular parte de tais recursos para outros fins não estritamente sociais" (CARDOSO; CASTRO, 2006, p. 147).

Saiu-se de uma carga tributária de 25,3\% em 1993 para algo em torno de 36,56\% em 2008, segundo informações divulgadas pelo Instituto Brasileiro de Planejamento Tributário, IBPT (2008).

Santos (2008), pesquisador e Coordenador de Finanças Públicas do IPEA, salienta que a carga tributária cresceu de $25 \%$ em meados dos anos 1990 para algo em torno de $35 \%$ em 2008 .

Cardoso e Castro (2006, p. 147-148) acrescentam ainda que o aumento da carga tributária destinada ao aumento das contribuições sociais, criando novas vinculações constitucionais, não se refletiu em aumento dos gastos sociais na mesma proporção devido à possibilidade de aplicação da DRU. O que ocorreu foi um incremento das despesas 
financeiras. Pode-se afirmar então que a estratégia macroeconômica do governo no período imputou ao lado social o aumento da arrecadação, mas não repassou o potencial de financiamento aos gastos sociais em seu conjunto.

Ferreira, Siqueira e Silva (2006, p. 31) analisam que a crescente carga tributária faz com que os produtos e serviços fiquem mais caros, impedindo, que muitas famílias possam comprá-los, e isto compromete o desempenho da indústria e serviços, que por não ter um mercado consumidor forte não cria novos empregos, e ainda, inibe o crescimento da atividade econômica.

Observa-se que as transferências, principalmente, do orçamento da seguridade social para o orçamento fiscal da União foram os grandes responsáveis pela situação na qual uma "parte estimada anualmente entre $1 \%$ e $2 \%$ do PIB é arrecadada em nome da área social, mas a ela não integralmente repassada" (CARDOSO; CASTRO, 2006, p. 165).

Conforme análise efetuada por Fraga (2000, p. 10), a transferência de recursos deveria ocorrer da forma inversa, ou seja, caso o orçamento da seguridade social não seja suficiente para seu custeio este deverá ser coberto por meio do orçamento fiscal e fundamenta sua análise na Constituição Federal,

ao estabelecer em seu art. 195 que a seguridade social será financiada por toda a sociedade, mediante recursos dos orçamentos da União, remete necessariamente ao parágrafo 5o do art. 165, que reza que a lei orçamentária compreenderá: I. o orçamento fiscal; ... III. o orçamento da seguridade social (FRAGA, 2000, p. 10).

Como visto anteriormente, esse deslocamento de recursos se deu através da DRU e teve como intuito principal o atendimento à política fiscal, destinando parte dos recursos à formação do superávit primário, ao atendimento de despesas obrigatórias e à despesa financeira, principalmente juros e encargos.

Para atendimento da função estabilizadora do governo federal e condução da política fiscal estabelecida, foram mantidos superávits primários elevados para garantir o refinanciamento da dívida pública, e transmitir a sensação de credibilidade e de governabilidade em prol da estabilização monetária.

O superávit primário previsto no PPA 2004/2007 é de R\$ 70 bilhões. Assim, pretende o governo fazer um superávit maior do que todos os seus gastos nas áreas sociais, conforme foi levantado por Ferreira, Siqueira e Silva (2006, p. 29). Entretanto, como se verá no Gráfico 3, onde se demonstra o superávit primário do setor público consolidado, verificou-se que os valores obtidos chegaram a 101,6 bilhões em 2007 e 118 bilhões em 2008. Valores esses bem superiores ao previsto inicialmente pelo PPA. 
Conforme lembrado por Castro (2003, p. 18), no caso brasileiro, existe um grande estoque de necessidades sociais insatisfeitas, tendo sido muitas até mesmo transformadas em direitos sociais na Constituição Federal de 1988. "A implementação, de forma articulada, de políticas adequadas (em quantidade e qualidade) que atendam a essas necessidades sociais, certamente demandaria uma alocação maior de recursos públicos do que a atual".

Diante do exposto, duas consequiências se manifestam do ponto de vista da gestão social:

i) as políticas sociais setoriais tornam-se insuficientes, diante do quadro de restrições macroeconômicas, para combater a estrutura de desigualdades da sociedade brasileira;

ii) os gastos sociais tradicionais tendem a se transformar na nova fronteira do superávit primário (CARDOSO; CASTRO, 2006, p. 171).

Rezende (2007, p. 328) faz uma análise de fundamental importância sobre o desafio do Brasil e demais países em desenvolvimento frente à teoria do capital humano de Theodore Schultz, surgido na década de 60,

Para Schultz, o crescimento econômico dos países não poderia ser totalmente explicado por fatores tradicionais, como capital físico (máquinas, equipamentos, construções), quantidade de mão-de-obra e recursos naturais (terra, reservas minerais, etc). A qualidade dos recursos humanos na forma de habilidades e conhecimentos representa importante determinante do desenvolvimento econômico. A formação de capital humano é dada a partir de investimentos em pessoas na aquisição de habilidades e conhecimentos úteis que geram um fluxo de rendimentos futuros. Os principais itens de gastos que podem ser considerados investimento em capital humano são: educação, saúde e treinamento no local de trabalho.

A melhoria das condições sanitárias, o acesso a moradias e à alimentação adequadas são medidas que elevam o padrão de vida da população, melhorando a qualidade dos recursos humanos.

Portanto, a absorção de novas tecnologias exige da população maior nível de escolaridade e capacidade para adquirir novos conhecimentos.

A melhoria do capital humano não afeta somente as variáveis econômicas, mas também os indicadores sociais (REZENDE, 2007, p.328).

A teoria do capital humano de Schultz reforça a preocupação que os países desenvolvidos têm com investimentos em políticas sociais, isto tem reduzido a desigualdade social e traz bem-estar à sociedade, com conseqüente crescimento econômico para o país. 


\section{5 - A DRU afeta o Gasto Social}

Como citado anteriormente na seção 2.1, a DRU é a sigla para Desvinculação de Recursos da União. O princípio orçamentário da não-vinculação ou não-afetação das receitas permitiu e até mesmo justificou a criação da DRU: "Nenhuma parcela da receita geral poderá ser reservada ou comprometida para atender a certos casos ou determinados gastos" (SILVA, 1962, p. 52). Este princípio é contrário a vinculação de receitas, saída encontrada pelo congresso para garantir a alocação de recursos para determinados segmentos da política social.

A análise que se deseja fazer é se a DRU trouxe impacto nos gastos sociais, e o que se apurou foi que no período de 1995 a 1998, uma parte desses recursos voltou para a área social. Conforme levantado por Cardoso e Castro (2006, p. 159), o financiamento de uma parcela expressiva dos gastos totais se deu em 1995 na ordem de 24\% e em 1998 na ordem de $17,9 \%$.

A partir de 1999, contudo, os recursos desvinculados por meio da DRU deixaram de contribuir exclusivamente para a área social e passaram a compor a estratégia de superávit primário do governo federal. "Por meio desse expediente, processa-se, então, uma transferência não desprezível de recursos do lado real da economia, e mais explicitamente, da área social, para a gestão financeirizada da dívida pública" (CARDOSO; CASTRO, 2006, p. 159-160).

Sabe-se que uma parte desses recursos volta para o gasto social, mas caiu fortemente a partir de 1999, ver Figura 3. Grande parte desses recursos tem sido destinada à geração de superávit primário, destinada ao pagamento de parte dos juros da dívida pública.

O orçamento deficitário da Seguridade Social faz com que uma parte dos recursos desvinculados através da DRU seja destinado ao financiamento de despesas com previdência social e assistência social, ou seja, uma parte do orçamento fiscal que foi formado pela desvinculação da DRU é destinado a cobrir o déficit do orçamento da seguridade social.

Essa questão é relatada pela SOF (2003, p. 19) da seguinte forma:

Apesar de a DRU contribuir para a ampliação dos recursos livres do orçamento Fiscal da União, a obrigatoriedade de pagamento de algumas despesas acaba revertendo essa situação. A Lei Orçamentária Anual - LOA 2002, aloca R\$ 17,2 
bilhões de receitas do orçamento Fiscal para o financiamento das despesas do orçamento deficitário da Seguridade Social. Na LOA, o montante de receitas de contribuições sociais desvinculadas por meio da DRU é de R \$20,5 bilhões. Assim, apenas $\mathrm{R} \$ 3,3$ bilhões são efetivamente liberados para serem utilizados livremente no orçamento Fiscal. Situação equivalente ocorre em 2003 (SOF, 2003, p. 19).

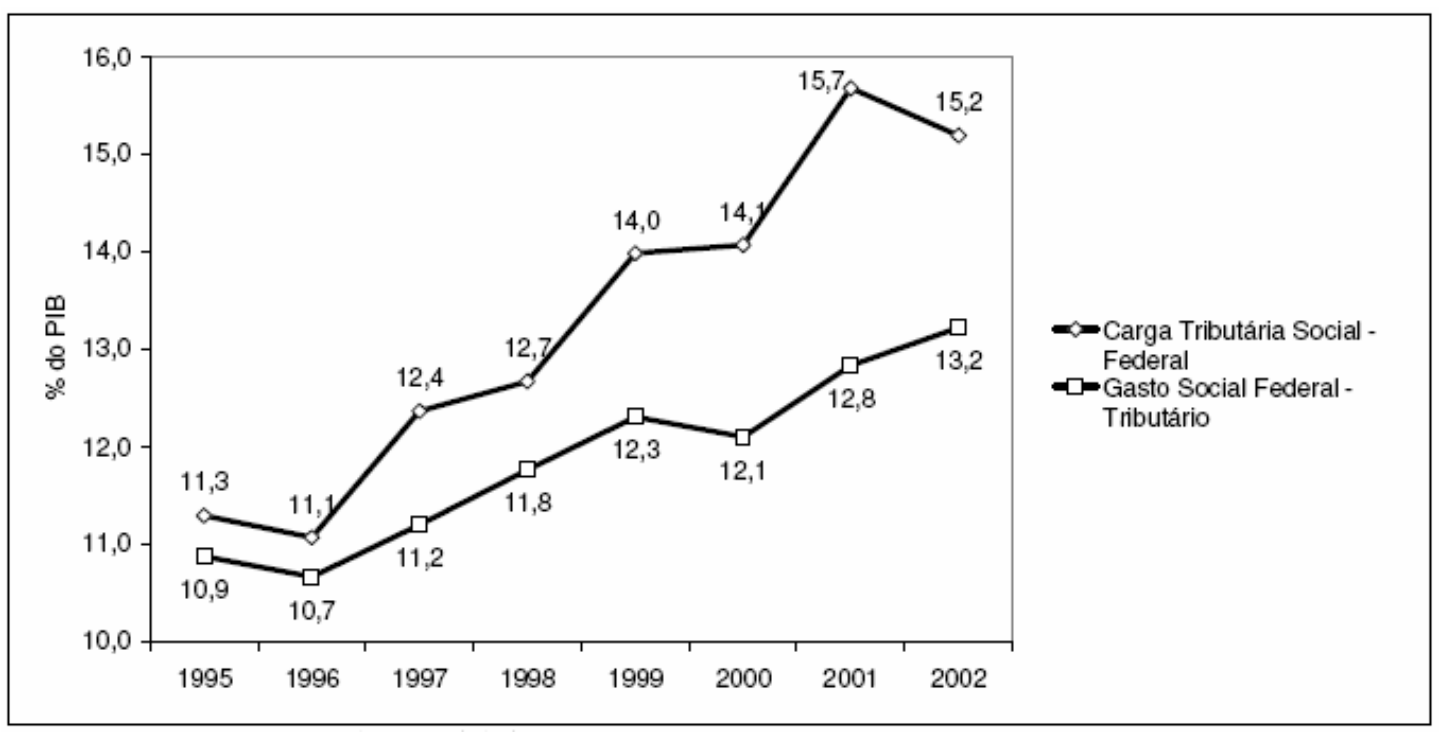

Figura 3 - Carga tributária social federal e gasto social federal Fonte: Cardoso e Castro (2006, p. 166).

Viu-se que a estratégia macroeconômica adotada pelo governo fez com que se optasse por expandir a arrecadação das contribuições sociais na composição total da carga tributária, já que a receita desses tributos não é repassada a estados e municípios. Mas dado que as contribuições sociais existem tendo por trás vinculações orçamentárias específicas, foi preciso que o governo criasse formas de desvinculação de parte desses recursos, o que foi feito através da DRU. No entanto, apesar do deficitário orçamento da seguridade social, somente uma parte dos recursos desvinculados retornam para cobrir o rombo orçamentário causado em grande parte pela previdência social. O restante é destinado à política fiscal do governo de pagamento dos juros da dívida.

"Pode-se afirmar que a estratégia de financiamento federal dos anos 1990 no Brasil logrou deslocar recursos potenciais do orçamento social para o ajuste macroeconômico, colocando um teto à capacidade de gastos sociais no período considerado." (CARDOSO; CASTRO, 2006, p. 169).

Embora o aumento da carga tributária federal tenha sido proveniente, em larga medida, do aumento da carga tributária de vinculação social, os gastos sociais não aumentaram na mesma magnitude, devido à desvinculação de parte destes recursos para livre uso pela União. Embora não tenha havido queda absoluta dos gastos sociais entre 1995-2002, seu ritmo de crescimento foi inferior ao 
crescimento dos recursos legalmente vinculados à área social (CARDOSO; CASTRO, 2006, p. 174).

Diante do exposto, viu-se que a DRU desvincula parte dos recursos orçamentários destinado aos gastos sociais, mas não é o grande responsável pela deficiência orçamentária em investimento com políticas sociais, sendo o deslocamento de recursos para formação do superávit primário muito mais expressivo.

Cabe ressaltar o preconizado pelo economista Osvaldo Kacef, "o que tem impacto no nível de atividade é o aumento do gasto público". Ele defende que este gasto deva ser feito em políticas públicas que gerem emprego e desenvolvimento social (KACEF, 2009). 


\section{3 - METODOLOGIA}

O objetivo fundamental da ciência é chegar à veracidade dos fatos por meio de um método que permita atingir determinado conhecimento. Define-se método como "o caminho para se chegar a determinado fim. E método científico como o conjunto de procedimentos intelectuais e técnicos adotados para se atingir o conhecimento" (GIL, 1994, p. 27).

Pretende-se aqui descrever a metodologia e técnicas de pesquisa que foram utilizadas para obtenção da informação desejada.

Descreveu-se mais detalhadamente nos próximos tópicos como ocorreu a pesquisa, seu tipo, amostra, os procedimentos adotados e a análise das informações.

\section{1 - Tipo de pesquisa}

O trabalho se utilizou das técnicas da pesquisa documental para o trabalho de abordagem dos dados a fim de obter a informação desejada. Apesar de a pesquisa documental ser considerada como pesquisa qualitativa, a pesquisa efetuada foi marcada

principalmente pelas características da pesquisa quantitativa, pois a coleta de dados se baseou em dados oficiais publicados pelo Governo, permitindo uma análise quantitativa.

Para fundamentar a escolha, Godoy (1995b, p. 66) aponta a existência de, pelo menos, três diferentes possibilidades oferecidas pela "abordagem qualitativa: a pesquisa documental, o estudo de caso e a etnografia".

Ainda segundo Godoy (1995a, p. 62), a pesquisa qualitativa é descritiva e tem ai um papel fundamental no processo de obtenção de dados e na disseminação dos resultados.

A principal diferença entre a pesquisa quantitativa, aonde o pesquisador conduz seu trabalho a partir de um plano estabelecido com hipóteses claramente especificadas e variáveis operacionalmente definidas, é que na pesquisa qualitativa não se procura enumerar ou medir os eventos estudados. Parte das questões vai se definindo à medida que o estudo se desenvolve, salienta Godoy (1995a, p. 58). 
A pesquisa documental, como o nome diz, é uma pesquisa baseada em documentos. Assemelha-se à pesquisa bibliográfica, todavia as fontes que a constituem são documentos e não livros publicados e artigos científicos divulgados, como é o caso da pesquisa bibliográfica. Ao invés disso, você obtém informações através da análise de documentos pré-existentes, objetivando tirar conclusões para o problema em questão, objeto da pesquisa.

A pesquisa documental é constituída pelo exame de materiais que ainda não receberam um tratamento analítico ou que podem ser reexaminados com vistas a uma interpretação nova ou complementar. Pode oferecer base útil para outros tipos de estudos qualitativos e possibilita que a criatividade do pesquisador dirija a investigação por enfoques diferenciados. Além disto, os documentos são uma fonte não-reativa e especialmente propícia para o estudo de longos períodos de tempo (NEVES, 1996, p. 3).

Conforme Gil (1991), a pesquisa a ser realizada do tipo análise documental pode-se constituir numa técnica valiosa de abordagem de dados qualitativos, seja complementando as informações obtidas por outras técnicas, seja desvelando aspectos novos de um tema ou problema.

Conforme analisado por Gil (1991, p. 27), uma das vantagens da pesquisa documental é o fato de não exigir contato com os sujeitos da pesquisa. Em muitos casos o "contato com o sujeito é difícil ou até mesmo impossível. Em outros casos, a informação proporcionada pelos sujeitos é prejudicada pelas circunstâncias que envolvem o contato".

\section{2 - Amostra de documentos}

Segundo Gil (1991), a pesquisa documental vale-se de materiais que não receberam ainda um tratamento analítico, ou que ainda podem ser re-elaborados de acordo com os objetos da pesquisa. Neste tipo de pesquisa as fontes de dados são muito mais diversificadas e dispersas, se comparado a pesquisa bibliográfica.

Ainda segundo Gil (1991) há documentos de primeira e segunda mão. O primeiro refere-se a documentos que ainda não receberam nenhum tratamento analítico. $\mathrm{O}$ segundo classificam-se os documentos que de alguma forma foram analisados, tais como: tabelas estatísticas e relatórios de pesquisa.

Optou-se nessa pesquisa por utilizar os dados publicados pelos principais órgãos do Governo Federal, BACEN, STN, SOF, IPEA, IBGE. A pesquisa se baseou em documentos 
de segunda mão, em sua maioria tabelas contendo informações diversas e que são publicadas com periodicidade definida. Foi necessário fazer combinação dos dados existentes em documentos distintos, selecionando-se os dados desejados, o que exigiu primeiramente um levantamento dos dados existentes e posterior análise para obtenção da informação desejada.

\section{3 - Procedimentos da Coleta de Dados}

A pesquisa teve como base uma série estatística formada pela análise histórica dos últimos 9 (nove) anos, tendo como fonte de informação os dados oficiais publicados pelos seguintes órgãos: Secretaria de Orçamento e Federal (SOF), Secretaria do Tesouro Nacional (STN), Banco Central do Brasil (BACEN), Instituto de Pesquisa Econômica Aplicada (IPEA) e Instituto Brasileiro de Geografia e Estatística (IBGE). Além disto, foram utilizadas outras fontes de dados como: LOA - Lei Orçamentária Anual e LDO Lei de Diretrizes Orçamentária.

Os dados foram coletados por meio de acesso aos sítios oficiais dos órgãos citados. Posteriormente, efetuada a seleção e análise dos dados, agrupando-os em tabelas auxiliares, gerando-se gráficos, de forma que se obtiveram os objetivos estabelecidos.

As informações coletadas dizem respeito ao orçamento da União com âmbito de pesquisa: Federal, Estadual, Municipal e Empresas Estatais.

\section{4 - Análise dos dados}

Com base nos dados coletados, foram construídas outras tabelas que permitiram gerar gráficos de projeções das informações, elaborado de maneira a investigar e a comprovar as expectativas dos objetivos estabelecidos.

O resultado gerou uma série de estatísticas que foram construídas com base nos dados levantados, o que permitiu analisar o problema de pesquisa. 
Os dados foram analisados com base nos gráficos e nas tabelas auxiliares, instrumento principal da pesquisa, o que permitiu obter os resultados descritos na seção seguinte.

Para analisar os dados do Gasto Social foram utilizadas informações oriundas do SIAFI - Sistema de Administração Financeira, que tem a estrutura de classificação das informações oriundas do orçamento público federal. A despesa pública, de acordo com a Lei 4320/64: art. $2^{\circ}, \S 1^{\circ}$, II e art. $8^{\circ}, \S 2^{\circ}$ e Portarias 42/99 e 163/2001 do Ministério do Planejamento Orçamento e Gestão, pode ser obtida através das seguintes classificações: Institucional, Funcional, Estrutural Programática e Natureza da Despesa.

Optou-se pela utilização da classificação funcional da despesa, pois "a finalidade principal da classificação funcional é fornecer as bases para a apresentação de dados e estatísticas sobre os gastos públicos nos principais segmentos em que atuam as organizações do Estado" (GIACOMONI, 2003, p. 98).

A classificação dos gastos públicos segundo a classificação funcional da despesa é composta por um conjunto de funções e subfunções previamente fixadas, agregando os gastos públicos por área de ação governamental nas três esferas: União, estados e municípios. Por ser de aplicação comum e obrigatória, a classificação funcional permite a consolidação nacional dos gastos do setor público. A função representa o maior nível de agregação da despesa do setor público e é composta por 28 funções.

Para este trabalho foram listados os direitos sociais, assegurados pela Constituição Federal juntamente com seus complementos, e correlacionados com as funções orçamentárias prevista na classificação funcional: educação, saúde, trabalho, direitos trabalhistas (Trabalho), moradia (Habitação), lazer (Desporto e Lazer), segurança (Segurança Pública), previdência social, proteção à maternidade e à infância (Assistência Social), assistência aos desamparados (Assistência Social), cultura, habitação, urbanismo, saneamento básico (Saneamento), meio ambiente (Gestão Ambiental), organização agrária e ciência e tecnologia.

A título de esclarecimento, a função Encargos Especiais "engloba as despesas em relação às quais não se possa associar um bem ou serviço a ser gerado no processo produtivo corrente, tais como: dívidas, ressarcimentos, indenizações e outras afins, representando, portanto, uma agregação neutra" (Brasil, Portaria n 42, de 14-04-1999: art. $\left.1^{\mathrm{o}}, \S 2^{\mathrm{o}}\right)$. 


\section{4 - RESULTADOS E DISCUSSÕES}

A descrição da análise e dos resultados obtidos é apresentada em três seções distintas para melhor entendimento do leitor e demonstrando de forma evolutiva as conclusões que a pesquisa permitiu obter. Em cada seção são apresentados os objetivos atendidos, a forma de obtenção dos dados, a análise sobre as informações e são explanadas discussões sobre o assunto.

\section{1 - Análise do Gasto Social}

A análise dos dados do gasto social está associada à peça orçamentária e ao histórico de sua execução, ou seja, o que é orçado sobre o que realmente é executado. Estas informações são divulgadas à sociedade através de duas entidades governamentais chave, a Secretaria de Orçamento e Federal (SOF) e a Secretaria do Tesouro Nacional (STN).

Para possibilitar um estudo comparativo e análise do comportamento dos gastos públicos ao longo dos últimos anos, utilizou-se como parâmetro o PIB a preços de mercado que é divulgado através do relatório anual do BACEN. Este relatório utiliza como fonte de dados o PIB que é divulgado pelo Instituto Brasileiro de Geografia e Estatística (IBGE), órgão responsável pelo cálculo e publicação das informações relativas ao PIB.

A SOF publica periodicamente as informações relativas ao orçamento público e faz sua gestão. As publicações das informações são efetuadas desde sua elaboração em projetos de lei até sua aprovação, Lei Orçamentária Anual (LOA), e inclui legislações correlacionadas como a Lei de Diretrizes Orçamentária (LDO), que determina as diretrizes para a elaboração da LOA. Além disto, são publicados a Programação Orçamentária e Financeira anual e os relatórios de Avaliação Orçamentária trimestrais.

A STN publica periodicamente relatórios e indicadores relativos à execução orçamentária e financeira e faz sua gestão. As informações publicadas referem-se a um conjunto de dados que são extraídos e consolidados através do principal Sistema Integrado de Administração Financeira do país, SIAFI. 
O Gráfico 4 possibilita a visualização do comportamento do PIB ao longo do período analisado e demonstra em valores absolutos um crescimento de quase o triplo do volume negociado ou das riquezas produzidas no país em 9 anos.

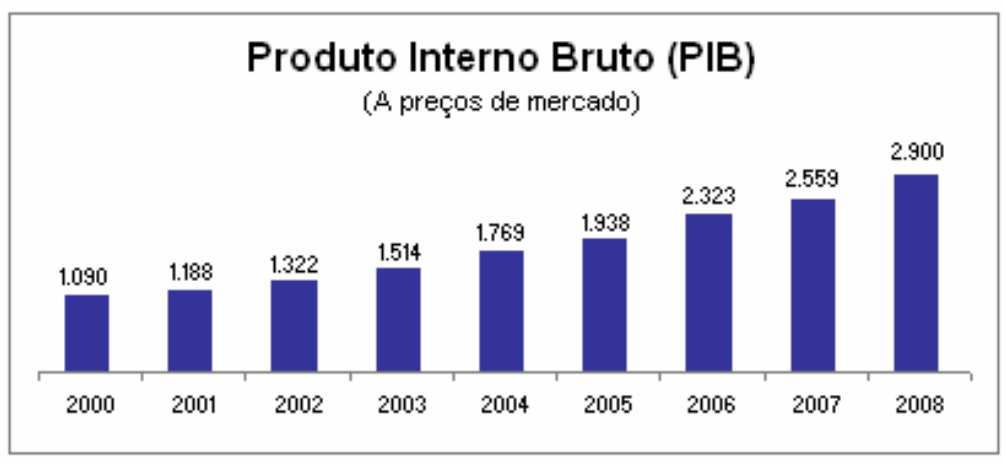

Gráfico 4 - Evolução do PIB

Fonte: Banco Central - BACEN e Instituto Brasileiro de Geografia e Estatística - IBGE

A extração e análise do gasto social foi possível graças à classificação das despesas orçamentárias por função. Essa classificação é oriunda do orçamento público federal, e é dentre as classificações orçamentárias a que melhor convém ao objeto de estudo.

As informações foram colhidas inicialmente no Portal da Transparência

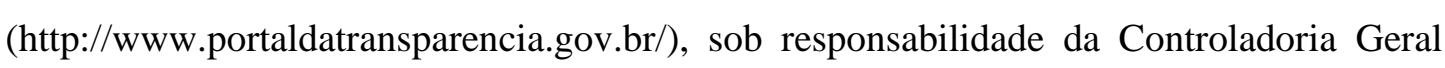
da União (CGU), que utiliza como fonte de dados o SIAFI. Optou-se então por extrair as informações diretamente do sistema utilizando-se o SIAFI Gerencial. Entretanto, os dados publicados no Siafi Gerencial referem-se ao ano atual e os últimos 5, o que limitaria a pesquisa em 5 anos. Posteriormente, foi obtido um relatório consolidado da STN contendo informações desde o ano de 1980. Entretanto, devido à mudança de classificação funcional ocorrida em 1999 optou-se por levantar as informações a partir do ano 2000 para possibilitar melhor qualidade da informação produzida.

Os dados referentes ao PIB foram coletados no portal do Instituto Brasileiro de Geografia e Estatística (IBGE) e refere-se ao indicador "Contas Nacionais PIB" divulgado trimestralmente (Tabela 2072 - Contas econômicas trimestrais), posteriormente, as informações coletadas foram comparadas com as dispostas no Relatório Anual do BACEN, que faz uma análise do PIB a preços de mercado. Optou-se por utilizar os dados publicados no BACEN. 
De posse das informações coletadas foram elaboradas as Tabelas 2 e 3, separadas para melhor visualização, que permitiram uma análise comparativa da aplicação de recursos em política social, e de onde se derivou a maior parte dos gráficos relacionados ao Gasto Social.

\begin{tabular}{|c|c|c|c|c|c|c|c|c|c|c|c|}
\hline \multirow{2}{*}{\multicolumn{2}{|c|}{ Código Llllome Função }} & \multicolumn{2}{|c|}{2000} & \multicolumn{2}{|c|}{2001} & \multicolumn{2}{|c|}{2002} & \multicolumn{2}{|c|}{2003} & \multicolumn{2}{|c|}{2004} \\
\hline & & Valor & $\%$ PIB & Valor & $\%$ PIB & Valor & $\%$ PIB & Valor & $\%$ PIB & Valor & $\% /$ PIB \\
\hline 06 & Segurança Pública & 2.189 & $0,20 \%$ & 2.604 & $0,22 \%$ & 2.202 & $0,17 \%$ & 2.405 & $0,16 \%$ & 2.768 & $0,16 \%$ \\
\hline 08 & Assistência Social & 4.442 & $0,41 \%$ & 5.298 & $0,45 \%$ & 6.513 & $0,49 \%$ & 8.416 & $0,56 \%$ & 13.863 & $0,78 \%$ \\
\hline 09 & Previdência Social & 93.408 & $8,57 \%$ & 107.544 & $9,05 \%$ & 123.218 & $9,32 \%$ & 145.478 & $9,61 \%$ & 165.509 & $9,36 \%$ \\
\hline 10 & Saúcle & 20.270 & $1,86 \%$ & 23.634 & $1,99 \%$ & 25.435 & $1,92 \%$ & 27.172 & $1,79 \%$ & 32.973 & $1,86 \%$ \\
\hline 11 & Trabalho & 6.246 & $0,57 \%$ & 7.441 & $0,63 \%$ & 8.478 & $0,64 \%$ & 9.495 & $0,63 \%$ & 10.707 & $0,61 \%$ \\
\hline 12 & Educaçäo & 10.616 & $0,97 \%$ & 11.637 & $0,98 \%$ & 13.223 & $1,00 \%$ & 14.224 & $0,94 \%$ & 14.533 & $0,82 \%$ \\
\hline 13 & Cultura & 238 & $0,02 \%$ & 278 & $0,02 \%$ & 240 & $0,02 \%$ & 231 & $0,02 \%$ & 324 & $0,02 \%$ \\
\hline 15 & Urbanismo & 190 & $0,02 \%$ & 491 & $0,04 \%$ & 487 & $0,04 \%$ & 343 & $0,02 \%$ & 1.193 & $0,07 \%$ \\
\hline 16 & Habitaçäo & 1.607 & $0,15 \%$ & 357 & $0,03 \%$ & 127 & $0,01 \%$ & 122 & $0,01 \%$ & 489 & $0,03 \%$ \\
\hline 17 & Saneamento & 161 & $0,01 \%$ & 233 & $0,02 \%$ & 97 & $0,01 \%$ & 59 & $0,00 \%$ & 77 & $0,00 \%$ \\
\hline 18 & Gestäo Ambiental & 1.139 & $0,10 \%$ & 1.899 & $0,16 \%$ & 1.265 & $0,10 \%$ & 948 & $0,06 \%$ & 1.193 & $0,07 \%$ \\
\hline 19 & Ciência e Tecnologia & 1.245 & $0,11 \%$ & 1.592 & $0,13 \%$ & 1.507 & $0,11 \%$ & 1.993 & $0,13 \%$ & 2.607 & $0,15 \%$ \\
\hline 21 & Organizaçäo Agrária & 1.093 & $0,10 \%$ & 1.330 & $0,11 \%$ & 1.381 & $0,10 \%$ & 1.430 & $0,09 \%$ & 2.618 & $0,15 \%$ \\
\hline 27 & Desporto e Lazer & 174 & $0,02 \%$ & 298 & $0,03 \%$ & 265 & $0,02 \%$ & 160 & $0,01 \%$ & 271 & $0,02 \%$ \\
\hline \multirow{3}{*}{$\begin{array}{l}\vec{a} \\
\stackrel{5}{\circ} \\
\end{array}$} & Gasto Social & 143.018 & $13,12 \%$ & 164.638 & $13,86 \%$ & 184.436 & $13,96 \%$ & 212.475 & $14,03 \%$ & 249.125 & $14,08 \%$ \\
\hline & Superávit Primário & 38.200 & $3,60 \%$ & 43.700 & $3,80 \%$ & 52.400 & $4,06 \%$ & 66.200 & $4,37 \%$ & 81.100 & $4,60 \%$ \\
\hline & PIB & 1.089 .700 & $100,00 \%$ & 1.187 .800 & $100,00 \%$ & 1.321 .500 & $100,00 \%$ & 1.514 .000 & $100,00 \%$ & 1.769 .000 & $100,00 \%$ \\
\hline
\end{tabular}

Tabela 2 - Gastos sociais por função e percentual sobre o PIB (2000 a 2004)

Fonte: Secretaria do Tesouro Nacional - STN, Banco Central - BACEN e Instituto Brasileiro de Geografia e Estatística - IBGE

\begin{tabular}{|c|c|c|c|c|c|c|c|c|c|}
\hline \multirow[b]{2}{*}{ Código } & \multirow[b]{2}{*}{ Ilome Funçąo } & \multicolumn{2}{|c|}{2005} & \multicolumn{2}{|c|}{2006} & \multicolumn{2}{|c|}{2007} & \multicolumn{2}{|c|}{2008} \\
\hline & & Valor & $\% /$ PIB & Valor & $\% /$ PIB & Valor & $\% /$ PIB & Valor & $\% /$ PIB \\
\hline 06 & Segurança Pública & 3.018 & $0,16 \%$ & 3.450 & $0,15 \%$ & 4.093 & $0,16 \%$ & 4.926 & $0,17 \%$ \\
\hline 08 & Assistência Social & 15.806 & $0,82 \%$ & 21.551 & $0,93 \%$ & 24.649 & $0,96 \%$ & 28.655 & $0,99 \%$ \\
\hline 09 & Previdência Social & 188.506 & $9,73 \%$ & 212.490 & $9,15 \%$ & 233.208 & $9,11 \%$ & 257.060 & $8,86 \%$ \\
\hline 10 & Saúcle & 36.483 & $1,88 \%$ & 39.736 & $1,71 \%$ & 39.434 & $1,54 \%$ & 43.633 & $1,50 \%$ \\
\hline 11 & Trabalho & 12.717 & $0,66 \%$ & 16.417 & $0,71 \%$ & 19.357 & $0,76 \%$ & 21.818 & $0,75 \%$ \\
\hline 12 & Educação & 16.188 & $0,84 \%$ & 17.336 & $0,75 \%$ & 18.890 & $0,74 \%$ & 21.924 & $0,76 \%$ \\
\hline 13 & Cultura & 494 & $0,03 \%$ & 552 & $0,02 \%$ & 414 & $0,02 \%$ & 513 & $0,02 \%$ \\
\hline 15 & Urbanismo & 2.111 & $0,11 \%$ & 2.118 & $0,09 \%$ & 848 & $0,03 \%$ & 1.081 & $0,04 \%$ \\
\hline 16 & Habitação & 570 & $0,03 \%$ & 1.167 & $0,05 \%$ & 0 & $0,00 \%$ & 153 & $0,01 \%$ \\
\hline 17 & Saneamento & 88 & $0,00 \%$ & 56 & $0,00 \%$ & 40 & $0,00 \%$ & 478 & $0,02 \%$ \\
\hline 18 & Gestäo Ambiental & 1.992 & $0,10 \%$ & 1.498 & $0,06 \%$ & 1.274 & $0,05 \%$ & 1.373 & $0,05 \%$ \\
\hline 19 & Ciência e Tecnologia & 3.274 & $0,17 \%$ & 3.703 & $0,16 \%$ & 3.207 & $0,13 \%$ & 3.951 & $0,14 \%$ \\
\hline 21 & Organizaçäo Agrária & 3.583 & $0,18 \%$ & 4.189 & $0,18 \%$ & 3.485 & $0,14 \%$ & 2.438 & $0,08 \%$ \\
\hline 27 & Desporto e Lazer & 423 & $0,02 \%$ & 736 & $0,03 \%$ & 754 & $0,03 \%$ & 202 & $0,01 \%$ \\
\hline \multirow{3}{*}{$\begin{array}{l}\mathbb{a} \\
\vdash \\
\vdash\end{array}$} & Gasto Social & 285.254 & $14,72 \%$ & 325.000 & $13,99 \%$ & 349.654 & $13,66 \%$ & 388.206 & $13,39 \%$ \\
\hline & Superávit Primário & 93.500 & $4,84 \%$ & 90.100 & $3,88 \%$ & 101.606 & $3,98 \%$ & 118.037 & $4,07 \%$ \\
\hline & PIB & 1.937 .600 & $100,00 \%$ & 2.322 .800 & $100,00 \%$ & 2.558 .800 & $100,00 \%$ & 2.900 .000 & $100,00 \%$ \\
\hline
\end{tabular}

Tabela 3 - Gastos sociais por função e percentual sobre o PIB (2005 a 2008)

Fonte: Secretaria do Tesouro Nacional - STN, Banco Central - BACEN e Instituto Brasileiro de Geografia e Estatística - IBGE

Disparadamente, o gasto social de maior relevância no orçamentário público é o da Previdência Social, que representa $67 \%$ do montante dos recursos destinados a política social do país e um valor em torno de $9 \%$ do PIB. Se comparar o período em valores absolutos, esse montante de recursos quase triplicou na última década. 
Enquanto o crescimento dos demais gastos sociais está associado à vinculação de receitas e uma maior arrecadação de impostos por parte do governo, o gasto com a previdência social está relacionado ao direito adquirido e às legislações vigentes, ou seja, independente do montante de recursos arrecadados. Em caso de déficit no orçamento da seguridade social (previdência, assistência social e saúde) este deverá ser coberto com recursos do orçamento fiscal. Observe no Gráfico 5 o crescimento avultoso de recursos da Previdência Social e que deixa os demais recursos quase que inexpressíveis, quando comparados de forma conjunta.

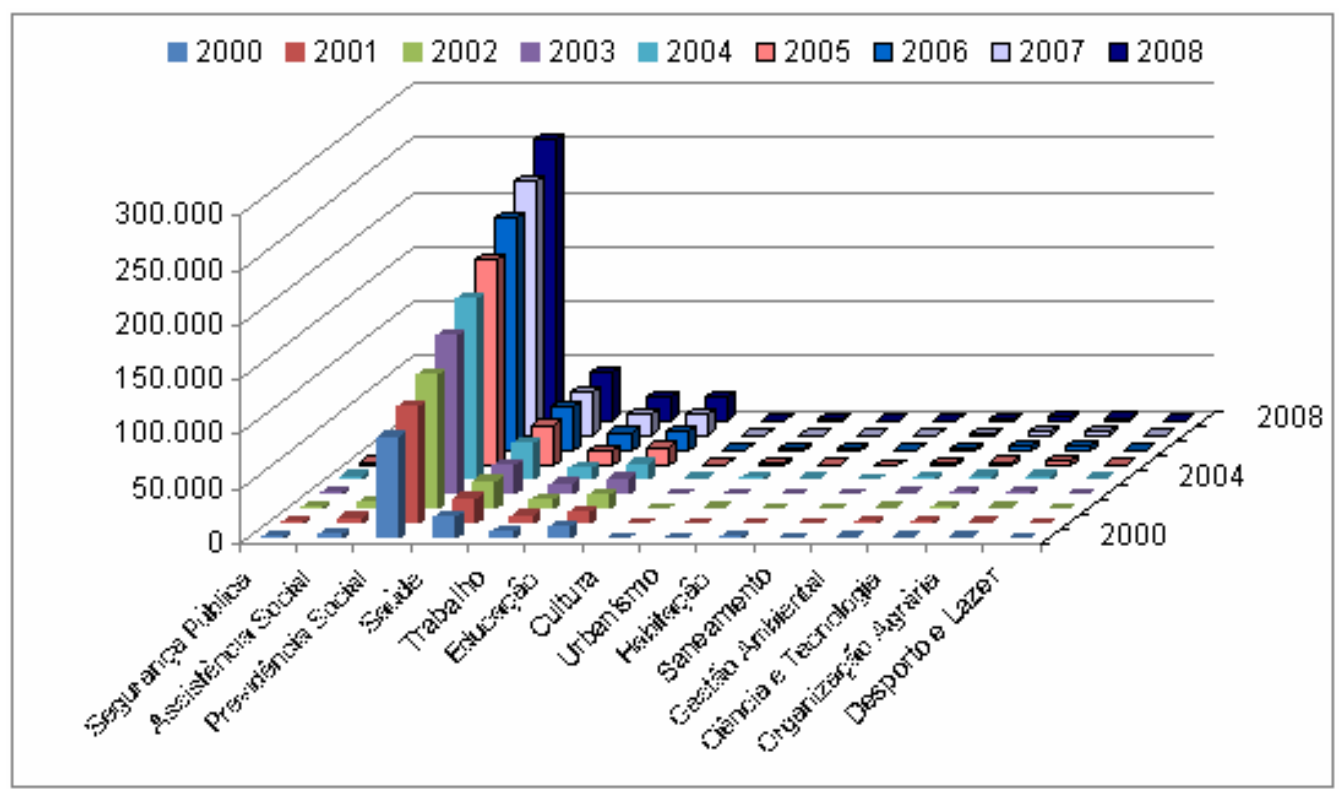

Gráfico 5 - Demonstrativo do crescimento dos gastos sociais

Fonte: Secretaria do Tesouro Nacional - STN, SIAFI

Para melhor visualização do comportamento da execução orçamentária frente às demais funções ligadas às políticas sociais foi elaborado o Gráfico 6, excluindo-se a função Previdência Social. Desta forma, podem-se visualizar as demais funções sociais, onde se destacam as principais em termos de destinação de recursos: Saúde, Assistência Social, Educação e Trabalho. 


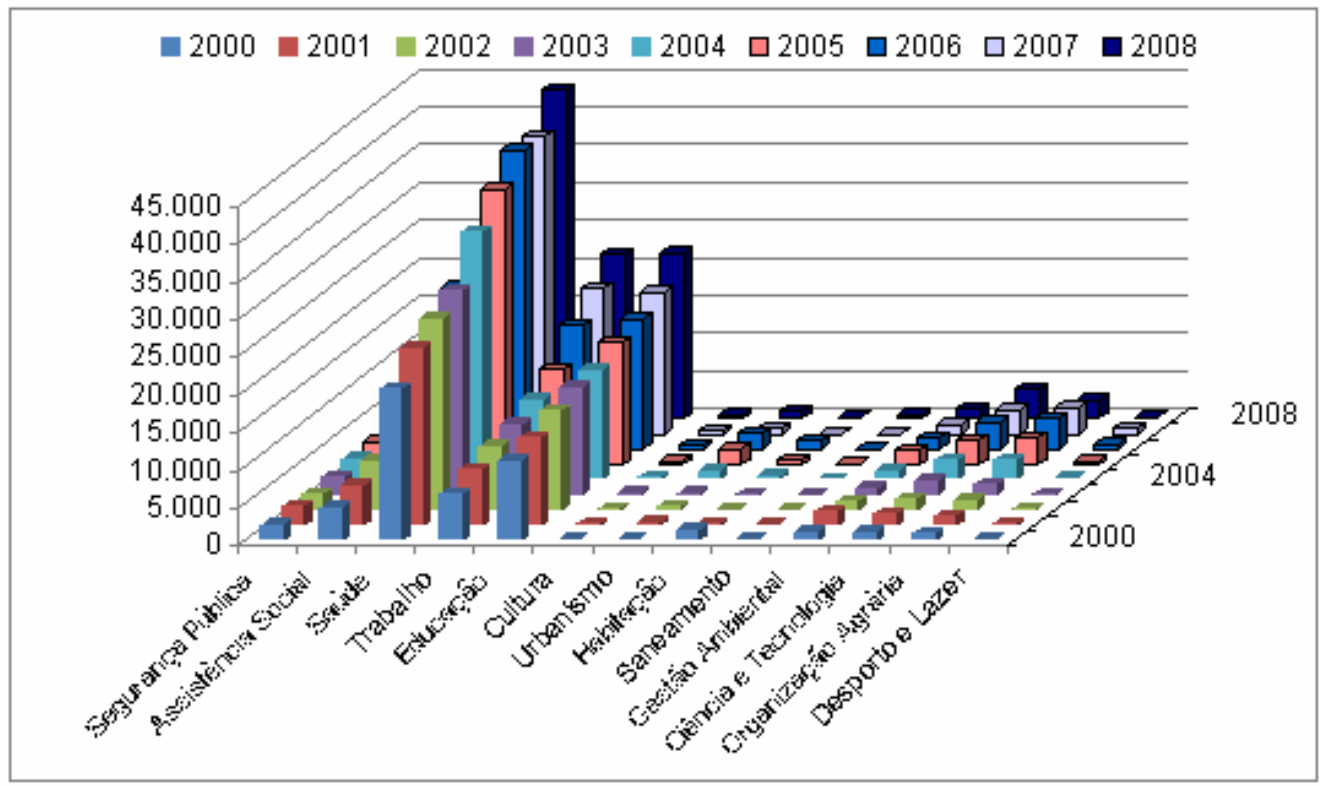

Gráfico 6 - Demonstrativo do crescimento dos gastos sociais, exceto previdência Fonte: Secretaria do Tesouro Nacional - STN, SIAFI

A Assistência Social também obteve um crescimento expressivo. Representa $7 \%$ do montante dos recursos destinados à política social do país e um valor em torno de $1 \%$ do PIB. Em 2000 foram destinados 3\% dos recursos da política social contra os atuais 7\%. Se comparar o período em valores absolutos, esse montante de recursos está 6,5 vezes maior. É importante ressaltar, que desde o ano de 2005 a destinação de recursos para assistência social é maior que o destinado à Educação.

Já a Saúde não obteve crescimento. Representa $11 \%$ do montante dos recursos destinados à política social do país contra os 14\% dos recursos destinados no ano 2000 e um valor em torno de $1,5 \%$ do PIB. Se comparar o período em valores absolutos, esse montante de recursos dobrou na última década, não acompanhando o crescimento do PIB, que quase triplicou. O montante de recursos destinado à saúde não acompanhou o crescimento das demais políticas sociais, sendo a mais afetada, principalmente, após a extinção da Contribuição Provisória sobre Movimentação Financeira (CPMF) em $31 / 12 / 2007$, criada com a finalidade de repasse dos recursos ao orçamento da seguridade social, sendo uma importante contribuição, destinava $0,20 \%$ a saúde, $0,10 \%$ a previdência e 0,8\% ao Fundo de Combate e Erradicação da Pobreza (Brasil, EC no. 37/2002, art. 84 e EC no. 42/2003, art. 90).

A Educação também não obteve crescimento. Representa $6 \%$ do montante dos recursos destinados à política social do país contra os $7 \%$ dos recursos destinados no ano 
2000 e um valor em torno de $0,76 \%$ do PIB. Se comparar o período em valores absolutos, esse montante de recursos dobrou na última década, não acompanhando o crescimento do $\mathrm{PIB}$, que quase triplicou.

Neste ano de 2009, se discute no Congresso Nacional a possibilidade da DRU não desvincular os recursos destinados à Educação, o que seria uma forma de ampliar os recursos destinados a esta função. De acordo com a matéria publicada no portal do Ministério da Educação (MEC)

\begin{abstract}
A proposta de emenda constitucional (PEC 96/03) que extingue a DRU para a área educacional deverá destinar integralmente $18 \%$ do total de recursos arrecadados com impostos federais à educação, como prevê a Constituição Federal de 1988. O fim da Desvinculação das Receitas da União (DRU) para a educação permitirá repor ao orçamento do MEC R \$ 7,5 bilhões por ano, de acordo com o ministro da Educação, Fernando Haddad (MACHADO, 2009).
\end{abstract}

Vale ressaltar que a teoria do capital humano de Theodore Schultz, surgido na década de 60 e descrito na seção 2.4 , defende que investir em pessoas, especialmente em educação, saúde e treinamento no local de trabalho, melhora o capital humano e afeta positivamente as variáveis econômicas e também os indicadores sociais.

O Trabalho obteve crescimento. Representa $6 \%$ do montante dos recursos destinados à política social do país contra os 4\% dos recursos destinados no ano 2000 e um valor em torno de $0,75 \%$ do PIB. Se comparar o período em valores absolutos, esse montante de recursos triplicou na última década, acompanhando o crescimento do PIB.
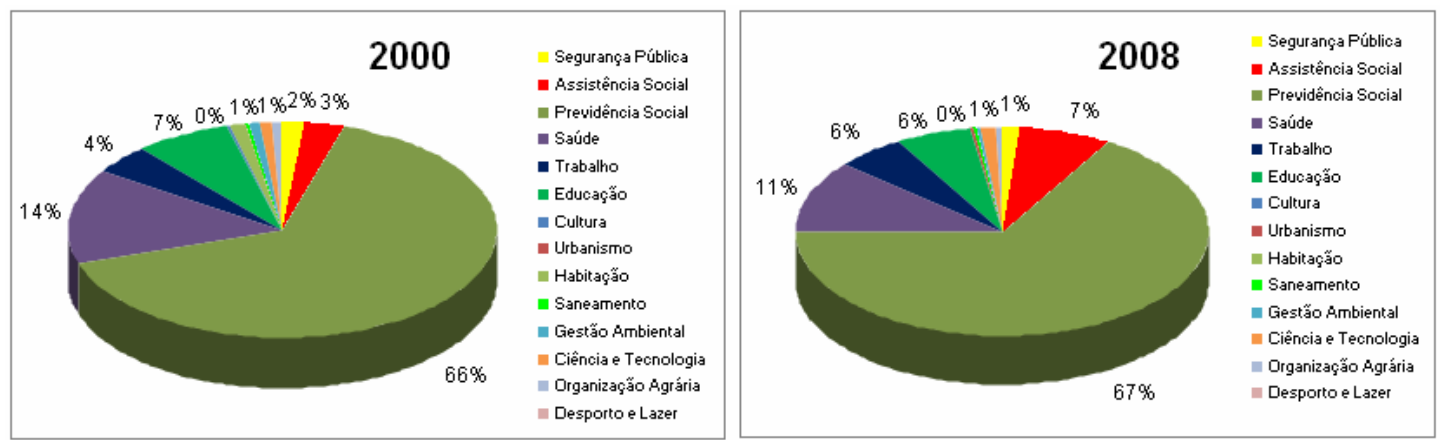

Gráfico 7 - Gastos sociais - comparação 2000 e 2008

Fonte: Secretaria do Tesouro Nacional - STN, SIAFI

Os demais gastos sociais representam apenas 3\% do montante dos recursos destinados à política social do país contra os $6 \%$ destinados no ano 2000 , e um valor em torno de $0,52 \%$ do PIB. Os gastos sociais com Urbanismo e Organização Agrária foram os que mais oscilaram ao longo do período tendo grandes variações de amplitude. Sofreram 
redução de recursos os gastos destinados às funções de Segurança Pública, Habitação, Gestão Ambiental, Organização Agrária, Desporto e Lazer. Já os recursos destinados as funções de Urbanismo, Saneamento, Ciência e Tecnologia sofreram crescimento, e a Cultura se manteve estável.

Diante do exposto, conclui-se um dos objetivos propostos neste trabalho, o de demonstrar com dados estatísticos os gastos sociais e as áreas que vem sendo afetadas.

\section{2 - Análise da DRU}

Como foi visto na seção 2.5, a vinculação de recursos para as políticas sociais iniciou-se como importante conquista a partir da Constituição de 1988. Os recursos originados na cobrança de taxas ou contribuições têm em comum uma relativa estabilidade na captação de recursos, deixando de depender de escolhas arbitrárias por parte do governo.

Entretanto, devido ao alto grau de vinculação de recursos do orçamento federal foi criada a Desvinculação de Receitas da União (DRU). Com aprovação da DRU a partir de 2000, não é mais possível distinguir os recursos que são desvinculados no orçamento, pois a DRU não está vinculada a nenhum fundo, ainda que somente contábil, como era o FEF. Essa regra impossibilita distinguir, na execução orçamentária, qual parcela de recursos é originária de impostos gerais, e qual é referente à desvinculação de recursos, já que ambas agora compõem a mesma fonte de Recursos Ordinários, salienta Salvador (2007).

Com a DRU, as arrecadações que seriam destinadas as políticas sociais, agora são destinadas a política fiscal. Na prática, todos os anos são desviados alguns bilhões de reais da saúde, educação, previdência, recursos estes transferidos das políticas sociais para realização do superávit primário.

Conforme análise efetuada por Salvador (2007), as políticas sociais mais prejudicadas pelo mecanismo da DRU são as da seguridade social e da educação. Em 2005, foram desvinculados $\mathrm{R} \$ 32$ bilhões da seguridade social, portanto, das políticas de saúde, previdência e assistência Social. Em 2006, os dados divulgados pela STN indicam que as receitas desviadas da seguridade social, alcançaram $\mathrm{R} \$ 33,8$ bilhões. Na educação estimase que os mecanismos de desvinculação de recursos (FSE, FEF e DRU) retiraram, em 12 
anos e em valores corrigidos pela inflação, R\$ 72 bilhões. Apenas no período de 2000 a 2007 foram R \$ 45,8 bilhões que deixaram de ser aplicados na educação. Somente em 2007 deixou-se de contar com $\mathrm{R} \$ 7,1$ bilhões.

Vale ressaltar, que esses recursos entram nos cofres públicos para serem aplicados nas políticas de assistência social, previdência e saúde, mas são canalizados para o orçamento fiscal, principalmente a composição do superávit primário.

Desta forma, por meio da DRU ocorre uma transformação dos recursos destinados às políticas sociais em dinheiro usado para pagar juros da dívida pública, uma vez que é composto o superávit primário.

Diante do exposto, concluí-se um dos objetivos propostos neste trabalho, o de analisar se a DRU está afetando o gasto social.

\section{3 - Análise do Superávit Primário}

Um dos objetivos deste trabalho é demonstrar a realização do superávit primário em números absolutos e em percentual sobre o PIB, e para tanto foi elaborado o gráfico demonstrativo do superávit primário executado pelo Setor Público Consolidado, formado pela União, estados, municípios e empresas estatais, demonstrando o grande esforço que o Governo juntamente com a sociedade tem feito para pagar os juros da dívida.

No ano de 2008 foram 118 bilhões de reais, o que representa 4,07\% do PIB contra os 3,8\% da meta estipulada na LDO, conforme informações dispostas nos Gráficos 2 e 3.

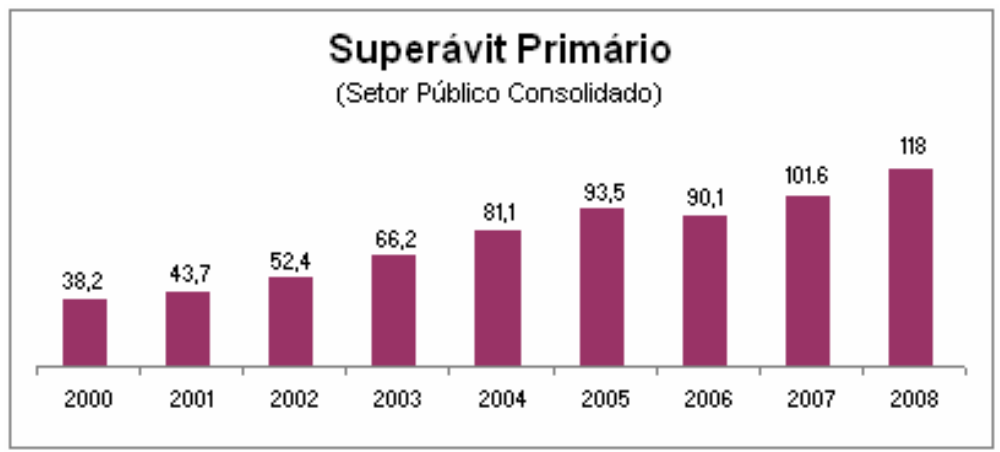

Gráfico 3 - Evolução do superávit primário Fonte: Banco Central - BACEN

* Setor Público Consolidado (União, Estados, Municípios e Estatais) 
Considerando que o esforço destina-se ao pagamento dos juros da dívida pública, segue uma reflexão sobre sua realidade.

A dívida líquida do setor público equivale a $36 \%$ do PIB, segundo informações do BACEN de dezembro de 2008, a manutenção de um superávit primário inferior a 3,8\% do PIB, levaria a uma trajetória de crescimento da dívida. Além disto, a simples percepção de insuficiência de superávit primário intensificaria a volatilidade do câmbio e pressão sobre os juros, consequientemente, piorando as condições de rolagem da dívida.

A Dívida Líquida do Setor Público (DLSP) cresceu quase cinco vezes em valores correntes, no período de 1994 a 2002. Em valores absolutos, praticamente triplicou. Diante do ocorrido e por força de acordo efetuado com o FMI em 1999, o governo teve de comprometer parcela considerável dos recursos que arrecada, deixando de realizar os gastos necessários nas políticas sociais, para produzir elevados superávits primários na execução dos orçamentos anuais.

O objetivo da política fiscal que vem sendo realizada no Brasil e sua necessidade de continuar para os próximos anos, de redução da relação dívida/PIB, implica, necessariamente, em manutenção do nível de superávit primário por um longo período, ultrapassando o tempo de mandato de um presidente, para obter o chamado déficit nominal zero. O que se tem vivido, atualmente, esforço conjunto Governo e sociedade, é conseqüência de um histórico de elevados gastos e empréstimos efetuados sem garantia de capacidade financeira para sustentar seu pagamento.

Entretanto, um dos objetivos deste trabalho é efetuar análise do superávit primário sob o gasto social, e isto foi demonstrado nos Gráficos 8 e 9 .

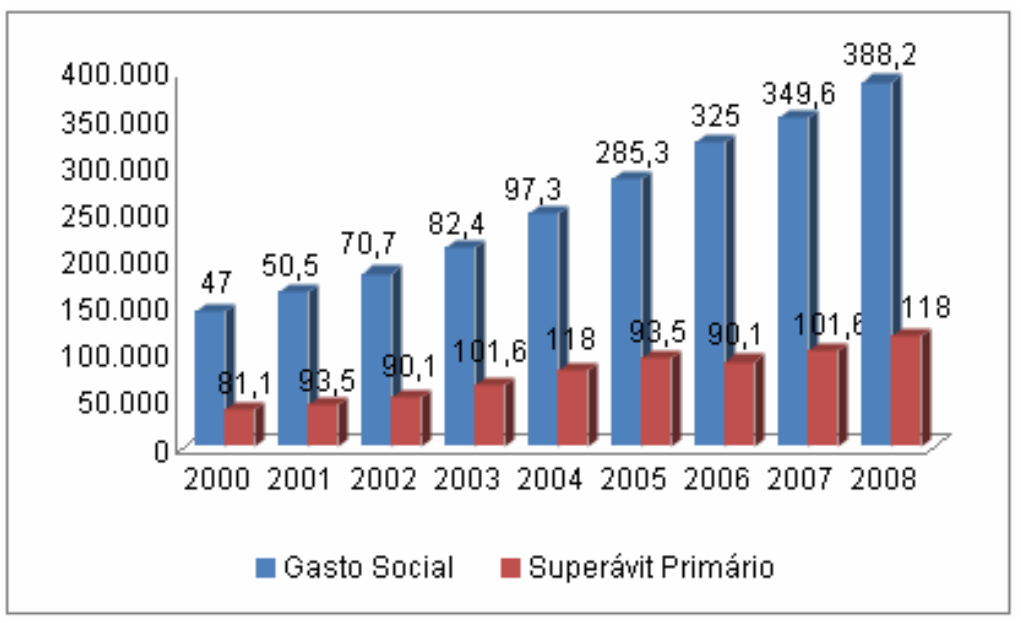

Gráfico 8 - Gastos sociais x superávit primário

Fonte: Secretaria do Tesouro Nacional - STN, SIAFI e Banco Central - BACEN 
No Gráfico 8 observa-se que tanto o gasto social quanto o superávit primário mantiveram uma tendência de crescimento. Se comparar o período em valores absolutos, o montante de recursos destinado aos gastos sociais está 8,2 vezes maior, enquanto o montante de recursos destinado ao superávit primário triplicou, acompanhando o crescimento do PIB.

Já no Gráfico 9, foi excluído o gasto social de maior relevância em termos de volume em repasse de recurso, que é a Previdência Social, e observa-se que apesar de mantida a tendência de crescimento do gasto social e do superávit primário, se comparar o período em valores absolutos, o montante de recursos destinado aos gastos sociais é apenas $11 \%$ maior que o superávit primário, simplesmente acompanhando o crescimento do PIB.

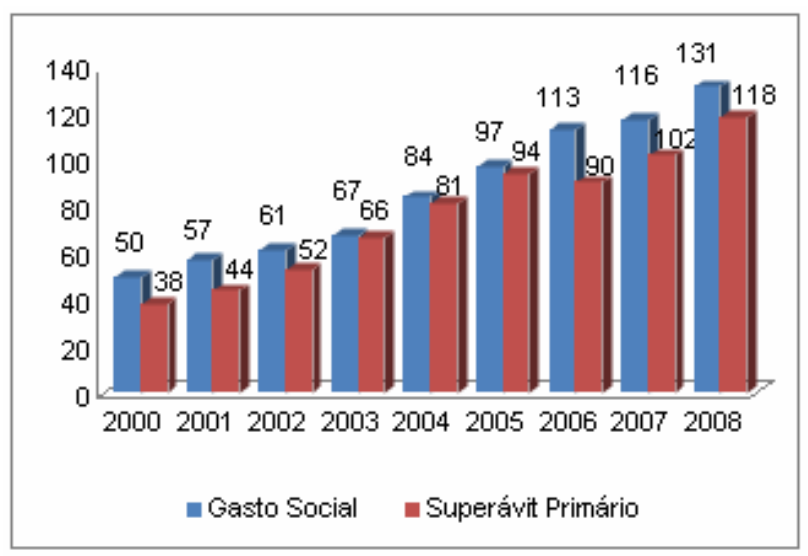

Gráfico 9 - Gastos sociais x superávit primário, exceto previdência social Fonte: Secretaria do Tesouro Nacional - STN, SIAFI e Banco Central - BACEN

A comparação nos permite refletir o quanto o gasto com a previdência social é expressivo e o quanto o superávit primário, por consequiência, a dívida pública, tem pesado no bolso dos Brasileiros. 


\section{5 - CONCLUSÃO}

O presente trabalho teve por objetivo avaliar a evolução do gasto social e da meta de superávit primário, tendo como indicador comparativo o PIB a preços de mercado, de forma a concluir se houve redução do gasto social em cumprimento à meta de Superávit Primário.

O debate teórico se pautou em: 1) explanar as funções de governo, sua importância e como ela está sendo afetada pela rigidez orçamentária. A importância da alocação de recursos, da distribuição de renda para redução da desigualdade social e da estabilidade econômica. 2) expor o problema da rigidez orçamentária, que ocasionou a necessidade de criação da DRU como mecanismo para destinação de recursos de forma livre, permitindo a atuação discricionária do Governo, o que tem sido utilizado para formação do superávit primário, e sua relação com o gasto social. 3) A eficácia do superávit primário como instrumento de política fiscal para obtenção do déficit nominal zero, equilíbrio das contas públicas e regulação da economia, com intuito de demonstrar aos investidores que o país é seguro para investimento. 4) A definição do que é considerado gasto social, sua relação com a evolução histórica da sociedade, sua importância e como ela está sendo afetada pela DRU.

O aumento da carga tributária foi justificado pela necessidade de aumento das contribuições sociais, o que criou novas vinculações constitucionais, entretanto, o aumento da arrecadação não se refletiu em aumento dos gastos sociais na mesma proporção, ou seja, em sua totalidade, devido à possibilidade de aplicação da DRU.

A DRU tem sido utilizada como auxílio para atendimento da política fiscal, destinando parte dos recursos à formação do superávit primário, à despesa financeira, principalmente juros e encargos, e ao atendimento de despesas obrigatórias.

No período coberto por esta monografia, ocorreu a adoção da LRF e de uma política fiscal de ajustes das contas públicas para assegurar o crescimento econômico sustentável. Conciliado com a explosão da dívida pública e a necessidade de seu pagamento, faz-se necessário seu controle ao ponto de nivelar o pagamento em níveis sustentáveis pela economia, ou seja, a obtenção do controle da dívida pública. 
Diante deste cenário, faz-se necessário a manutenção do superávit primário num patamar elevado. O governo passou a destinar um volume de recursos audacioso para formação do superávit primário, na tentativa de se obter, o quanto antes possível, o chamado déficit nominal zero, de forma que o orçamento seja capaz de pagar os juros da dívida, pois hoje paga-se somente parte dos juros.

Conclui-se que manter um superávit primário elevado para impedir o crescimento da dívida pública trouxe impacto nos gastos sociais, pois há uma demanda crescente de necessidades sociais que não foram compensadas com aumento do crescimento do PIB e da carga tributária. Vimos que alguns dos gastos sociais obtiveram elevação de seus gastos, acompanhando o crescimento do PIB, mas em compensação, os gastos com saúde e educação não obtiveram a mesma trajetória de crescimento, o que reflete em serviços com menor qualidade do que a esperada pela sociedade.

Outra questão, é que o gasto com a Previdência Social está muito elevado e isto também tem refletido nos demais gastos sociais, que ficam com seus orçamentos limitados devido à necessidade de atendimento despesas obrigatórias por conta de direitos adquiridos. Com exceção da Previdência Social, os recursos destinados aos demais gastos sociais somados equivalem-se ao montante destinado ao Superávit Primário, o que demonstra o tamanho do sacrifício que a sociedade tem feito para amenizar o problema da dívida. Se esse recurso pudesse ser repassado integralmente aos gastos sociais e ao investimento em infra-estrutura, certamente, teríamos maior qualidade de vida.

Cabe ressaltar, que a Assistência Social teve um crescimento bem acima dos padrões dos demais gastos sociais, o que demonstra a preocupação deste Governo com o atendimento desta necessidade social como forma de repasse e distribuição de renda.

Neste ano de 2009, vive-se a maior crise financeira mundial, sem precedentes na história, o que reflete um cenário inverso ao que se viveu nos últimos anos, de crescimento econômico mundial. A continuidade deste trabalho, incluindo análise do comportamento dos recursos em momento de recessão, poderá mostrar faces novas do problema de pesquisa, o que enriqueceria a análise dos dados, possibilitando a indicação de soluções para atendimento das necessidades sociais independentemente do momento econômico vivido pelo País. 


\title{
REFERÊNCIAS
}

\begin{abstract}
ALBUQUERQUE, C.; MEDEIROS, M.; FEIJÓ, P. Gestão de Finanças Públicas: Fundamentos e práticas de planejamento, orçamento e administração federal com responsabilidade fiscal. 2.ed. Brasília: Cidade Gráfica, 2008.
\end{abstract}

BRASIL. Constituição da República Federativa do Brasil: Texto constitucional promulgado em 05 de outubro de 1988, com as alterações adotadas pelas Emendas Constitucionais nos. 1/92 a 52/2006 e pelas Emendas Constitucionais de Revisão nos. 1 a 6/94. Brasília: Senado Federal, Subsecretaria de edições técnicas, 2006.

. Lei ${ }^{\circ} 10.934$, de 11 de agosto de 2004. Lei de Diretrizes Orçamentária - LDO 2005: Anexo de metas fiscais e relatório resumido da execução orçamentária: 7. ed. atual. Brasília: Secretaria do Tesouro Nacional, Coordenação-Geral de Contabilidade, 2005.

CARDOSO, J.; CASTRO, J. Economia política das finanças sociais brasileiras no período 1995-2002. Revista Economia e Sociedade, Campinas, v. 15, n. 1, p. 145-174, jan./jun. 2006.

CASTRO, J. et al. Análise da evolução e dinâmica do gasto social federal: 1995/2001. Brasília: Ipea, 2003. (Texto para Discussão, n. 988).

DEPARTAMENTO INTERSINDICAL DE ESTATÍSTICAS E ESTUDOS SOCIOECONÔMICOS. Nota Técnica: Dez perguntas e respostas para entender a dívida pública brasileira. DIEESE. NT. n. 14. Fev/2006.

FERNANDES, A. et al. Dimensionamento e Acompanhamento do Gasto Social Federal. Brasília: Ipea, 1998. (Texto para Discussão, n. 547).

FERREIRA, E; SIQUEIRA, G.; SILVA, G. A política superávit primário e suas conseqüências para a economia brasileira. 2006. F383p. Monografia (MBA em Finanças e Mercado de Capitais) - Universidade Cândido Mendes/GI \& P Escola de Negócios, Brasília, 2006.

FRAGA, E. A DRU e as receitas sociais vinculadas. Revista de Conjuntura CORECONDF, Brasília, jan./mar. 2000.

GIACOMONI, J. Orçamento Público: Revista e Atualizada. 12.ed. São Paulo: Atlas, 2003.

GIAMBIAGI, F. Em defesa de um superávit primário de 5\% do PIB. Revista Desafios do Desenvolvimento, Brasília, set. 2005. Disponível em: 'http://desafios.ipea.gov.br/desafios/edicoes/14/artigo13115-1.php 
GIAMBIAGI, F.; ALÉM, A. Finanças Públicas: teoria e prática no Brasil. 2.ed. Rio de Janeiro: Campus, 2001.

GIL, A. Como elaborar projetos de pesquisa. São Paulo: Atlas, 1991.

Métodos e técnicas de pesquisa social. São Paulo: Atlas, 1994.

GODOY, A. Introdução à pesquisa qualitativa e suas possibilidades. Revista de Administração de Empresa, São Paulo, v. 35, n. 2, p. 57-63, mar./abr. 1995a.

. A pesquisa qualitativa e sua utilização em administração de empresas. Revista de Administração de Empresa, São Paulo, v. 35, n. 4, p. 65-71, jul./ago. 1995 b.

GOLDFAJN, I. Nota Técnica: Há razões para duvidar que a dívida pública brasileira é sustentável?. BACEN. NT. n. 25. Jul/2002.

GOLDFAJN, I. Nota Técnica: Regras fiscais e sustentabilidade da dívida no Brasil. BACEN. NT. n. 39. Jul/2003.

INSTITUTO BRASILEIRO DE PLANEJAMENTO TRIBUTÁRIO. Estudos do IBPT. Carga tributária brasileira, Brasil, mar. 2009. Disponível em: http://www.ibpt.com.br/home/publicacao.view.php?publicacao id=13651\&PHPSESSID=d d $3 \mathrm{ec} 3 \mathrm{~d} 28 \mathrm{~b} 171484885457 \mathrm{dc} 121947 \mathrm{f}$

KACEF, O. Exibição de Notícias IPEA. Cepal recomenda gastar mais em infraestrutura e programas sociais, Brasil, mar. 2009. Disponível em:

'http://Www.ipea.gov.br/005/00502001.jS? ?ttCD_CHAVE=574

MACHADO, M. Destaques do Governo. Fim da DRU da educação, Brasil, mar. 2009.

Disponível em:

inttp://portal.mec.gov.br/index.php?id=10812\&option=com content\&task=view

MEIRELLES, H. Últimas notícias: Economia UOL. Elevar meta de superávit primário "é positivo", Brasil, mai. 2008. Disponível em:

hhttp://economia.uol.com.br/ultnot/valor/2008/05/13/ult1913us88474.jhtm

MUNHOZ, D. O Brasil e suas necessidades em infra-estrutura. Revista Universia atualidades, Brasil, dez. 2005. Disponível em:

'http://www.universia.com.br/materia/materia.jsp?id=9 $5 \overline{2} 2$

NEVES, J. Pesquisa Qualitativa: características, usos e possibilidades. Caderno de Pesquisas em Administração, São Paulo, v.1, n. 3, $2^{\circ}$ sem./1996. 
REZENDE, F. Finanças Públicas. 2.ed. São Paulo: Atlas, 2001.

Finanças Públicas. 2.ed. São Paulo: Atlas, 2007.

SANTOS, C. Reforma tributária. Exibição de Notícia do IPEA, Brasília, jul. 2008.

Disponível em:'http://Www.ipea.gov.br/003/00301009.jsp?ttCD_CHĀVE=5339'

SECRETARIA DE ORÇAMENTO FEDERAL. Vinculações de receitas dos orçamentos fiscal e da seguridade social e o poder discricionário de alocação dos recursos do governo federal. SOF, v.1, n. 1, fev. 2003.

SILVA, S. Os princípios orçamentários. Rio de Janeiro: Fundação Getúlio Vargas, 1962. (Conhecido como Sebastião de Sant'Anna e Silva) 


\section{ANEXO \\ METODOLOGIA DE CÁLCULO DO SUPERÁVIT PRIMÁRIO}

O resultado primário, que exclui das receitas totais os ganhos de aplicações financeiras e, dos gastos totais, os juros nominais devidos, mede como as ações correntes do setor público afetam a trajetória de seu endividamento líquido. O principal objetivo desse cálculo é avaliar a sustentabilidade da política fiscal em um dado exercício financeiro, tendo em vista o patamar atual da dívida consolidada e a capacidade de pagamento da mesma pelo setor público no longo prazo.

Os superávits primários são direcionados ao serviço da dívida, o que contribui para reduzir o estoque total da dívida líquida. Por sua vez, os déficits primários indicam a parcela do crescimento da dívida decorrente de financiamentos de gastos não-financeiros que excedem as receitas não-financeiras.

A metodologia de cálculo das Necessidades de Financiamento Líquido para o Governo Central sob o critério "acima da linha" (receitas menos despesas), enfoca a realização do gasto pela ótica de caixa e abrange as operações de todas as entidades nãofinanceiras da administração direta e indireta que compõem o Orçamento Geral da União (OGU). Cabe informar que tal metodologia de cálculo tem sido aprimorada nos últimos quinze anos, com objetivo de conferir maior grau de transparência e confiabilidade às estatísticas fiscais, face à complexidade do setor público brasileiro.

A apuração "acima da linha" iniciou-se em 1986, tendo por base o Orçamento Geral da União, em que se considerava, como despesa realizada, o valor da dotação orçamentaria mais créditos adicionais menos cancelamentos.

Em 1991, a mensuração do resultado fiscal passou a incorporar a informação disponível mais próxima da despesa efetiva e que proporcionava um acompanhamento mensal do déficit primário, tendo como fontes básicas de dados a execução financeira da Secretaria do Tesouro Nacional (STN), o fluxo de caixa do INSS, as liberações do Fundo de Amparo ao Trabalhador (FAT), os Documentos de Arrecadação de Receitas Federais (DARF) recolhidos à rede bancária da receita administrada pela SRF e outras que o órgão acompanha mensalmente, além da estimativa - com base no valor registrado na Lei Orçamentária - das demais receitas e despesas não captadas pelas informações disponíveis à época.

A partir de janeiro de 1998, os dados passaram a apresentar maior abrangência, refletindo o conjunto das transações efetuadas por todos os órgãos componentes do Orçamento Geral da União. Dessa forma, valores antes estimados passaram a ser registrados pelo seu valor realizado, como foi o caso das despesas efetuadas com recursos próprios da administração direta e indireta. Posteriormente, desde janeiro de 1999, a publicação "Resultado do Tesouro Nacional" passou a incluir no cálculo do resultado primário a arrecadação própria e os benefícios previdenciários pagos pelo INSS, com a incorporação de seu fluxo à Conta Única do Tesouro Nacional. Por fim, foram incluídas as operações primárias do Banco Central, o que tornou a abrangência das estatísticas "acima da linha" plenamente compatíveis com aquelas "abaixo da linha". 


\section{Detalhamento dos itens relevantes do Resultado Primário}

\section{I- Receita Total}

Corresponde ao total da receita primária arrecadada pela administração federal, distribuída em dois grandes grupos: Tesouro Nacional e Previdência Social. A receita do Tesouro com recursos obtidos com alienação de ações onde o governo detém a maioria do capital não são consideradas receitas primárias. Também não registra como receita as operações do Banco Central.

\section{I.1 Receita do Tesouro}

É a receita bruta do Tesouro Nacional, deduzidas as restituições e os incentivos fiscais. Abrange os recolhimentos efetuados pela administração direta, pelos fundos, autarquias e fundações integrantes do Orçamento Geral da União; inclui ainda as receitas de concessões de serviços ou de utilização do patrimônio público, como arrendamento e aluguel.

\section{I.1.1 Receita Bruta}

Como receita bruta entende-se todo o recolhimento bruto de tributos (impostos, taxas e contribuições sociais) e demais receitas parafiscais - como concessões, tarifas, aluguéis e receitas de participação acionária - da administração pública federal. São impostos: Imposto sobre importações (II), imposto sobre exportações (IE), imposto de renda (IR), imposto sobre operações financeiras (IOF), imposto sobre produtos industrializados (IPI) e imposto territorial rural (ITR).

São contribuições sociais: PIS/PASEP, Contribuição para o Financiamento da Seguridade Social (COFINS), Contribuição Provisória Sobre Movimentação Financeira (CPMF), Contribuição Sobre o Lucro Líquido das Empresas (CSLL), Contribuição para o Plano de Seguridade Social do Servidor Público (CSSP), contribuição para o Fundaf, contribuição do salário-educação e contribuição sobre receita de concurso de prognóstico.

Os impostos e as contribuições sociais - com exceção do salário-educação compõem praticamente a totalidade da receita administrada pela Secretaria da Receita Federal do Brasil. Seu recolhimento é efetuado por meio de DARF pela rede bancária credenciada, que tem até dois dias úteis para o repasse à Conta Única do Tesouro Nacional.

São demais receitas: recursos Parcela de Preços Específica (PPE), cujo objetivo é amortizar a dívida da Conta Petróleo do Tesouro junto à Petrobras; dividendos recebidos à conta do lucro de empresas estatais; concessões de serviços públicos e arrendamento do patrimônio; e "outras", que inclui taxas e receitas parafiscais, como tarifas, aluguéis, receita de prestação de serviço e rendas de alienação de ativos imobiliários. Uma parcela dessas "outras" receitas são recolhimentos próprios de órgãos da administração direta, fundos, autarquias e fundações.

As demais receitas recolhidas por meio de DARF são consideradas pela Secretaria da Receita Federal do Brasil como não administradas. Importante ressaltar que algumas 
dessas receitas são recolhidas diretamente à Conta do Tesouro, sem o preenchimento desse documento.

\section{I.1.2 Restituições e Incentivos Fiscais}

As restituições são devoluções aos contribuintes do imposto pago a maior. As maiores devoluções são relativas ao imposto de renda, e são efetuadas após a apuração do imposto devido para o ano de referência (ano-base), Os incentivos fiscais decorrem da opção pelo contribuinte pessoa jurídica por aplicação de até $40 \%$ do Imposto de Renda devido em fundos de investimento do Nordeste (Finor), da Amazônia (Finam) e do Espírito Santo (Funres).

\section{I.2 Receita da Previdência Social}

Corresponde à arrecadação de contribuições pelos trabalhadores da iniciativa privada ao Regime Geral de Previdência Social (RGPS) gerido pelo setor público federal, por meio o Instituto Nacional de Seguridade Social (INSS). O pagamento é efetuado por meio de Guias de Recolhimento da Previdência Social (GRPS) pela rede bancária. Também inclui o recolhimento à previdência através do sistema "Simples" e as demais receitas do INSS, como de aluguéis de imóveis. As receitas são líquidas de restituições e de transferências a terceiros de recursos oriundos das empresas contribuintes e destinados a outras instituições, como SENAC, SESI, SENAI, SESC e FNDE, entre outras.

Cabe ressaltar que, até 1998, as operações do INSS permaneciam fora da Conta Única do Tesouro Nacional. A inclusão dessas operações em setembro daquele ano teve por objetivo evitar o financiamento sistemático do INSS junto à rede bancária e a instituição de um mecanismo que garantisse a cobertura do Tesouro Nacional às insuficiências de caixa do INSS com a agilidade requerida e a um menor custo financeiro.

\section{II -Transferência a Estados e Municípios}

\section{II.1 Constitucionais}

Compreendem as parcelas de recursos do Imposto de Renda - IR e Imposto de Produtos Industrializados - IPI arrecadados pelo Governo Federal que são transferidas para os estados e municípios da seguinte forma:

FPE - Fundo de Participação dos Estados: 21,5\% do IR e 21,5\% do IPI;

FPM - Fundo de Participação dos Municípios: 22,5\% do IR e 22,5\% do IPI; e

FPEx - Fundo Constitucional de Compensação pela Exportação de Produtos Industrializados: $10 \%$ do IPI.

\section{II.2 Lei Complementar no $87 / 96$}

Repasses efetuados aos estados pela desoneração do ICMS para exportações de produtos primários e semi-elaborados e na aquisição de bens para integração do ativo permanente, segundo consta da Lei Complementar n ${ }^{\circ}$ 87/96.

\section{II.3 Demais Transferências}

Referem-se aos repasses de recursos oriundos de arrecadação do IOF-ouro (30\% aos estados e $70 \%$ aos municípios), do Imposto Territorial Rural - ITR (50\% aos 
municípios), do salário-educação (2/3 aos estados) e às transferências relativas a royalties pagos pela empresa Itaipu binacional, a royalties pagos pela Petrobras sob amparo da Lei $n^{\circ}$ 9.478/97, à parcela da União referente ao Fundef, além de transferências voluntárias decorrentes de convênios.

\section{III- Receita Líquida Total}

Corresponde ao total da receita primária arrecadada pela administração federal disponível para o custeio da máquina administrativa, alocação em atividades de governo e execução da política fiscal. É a receita bruta do Governo Central, deduzidas as restituições, os incentivos fiscais e as transferências a estados e municípios.

\section{IV- Despesa Total}

É o total da despesa primária realizada pela administração federal, sob a ótica de caixa. Corresponde ao total de cheques emitidos (Ordem Bancária - OB) pelos órgãos do governo federal para a realização de suas despesas, como pagamento de pessoal, custeio e investimento. Excluem-se dessas despesas pagamentos de juros, empréstimos e aplicações financeiras.

A execução orçamentária e financeira do Governo Federal registra a despesa em 3 momentos: (i) empenho, qual seja, o comprometimento da dotação orçamentária (recursos previstos no Orçamento para aquela despesa) com determinado gasto, já identificados a especificação, o credor e o montante; (ii) liquidação, que consiste no reconhecimento da dívida como líquida e certa, após a verificação das condições contratuais, dentre as quais a prestação do serviço ou a entrega do bem especificado; e (iii) pagamento, quando a Unidade Gestora do recurso público emite uma ordem bancária a favor do credor, contra a Conta Única do Tesouro Nacional (Lei n ${ }^{4} .320 / 64$ ).

O empenho não é condição suficiente para que a despesa seja efetivada, pois ainda pode ser cancelado, o que ocorre, geralmente, ao final do exercício. O empenho liquidado é o melhor indicador da despesa potencial do exercício, a qual, no entanto, somente é efetivada apenas quando emitida a ordem bancária em pagamento. Este é o critério de despesa considerado para o cálculo do resultado primário do Governo Central.

Observe-se que apenas uma parte da despesa do Tesouro Nacional, registrada na série estatística Execução Financeira do Tesouro, que é o fluxo de caixa da Secretaria do Tesouro Nacional, corresponde ao gasto efetivo, como as despesas com equalizações agrícolas pagas ao Banco do Brasil ou as transferências aos Fundos de Participação dos Estados e Municípios. Por sua vez, as despesas com custeio e investimento correspondem apenas ao repasse da Secretaria do Tesouro Nacional a outras Unidades Gestoras. O gasto efetivo - conceito utilizado na apuração de Necessidades de Financiamento - dá-se no dia seguinte ao da emissão de uma ordem bancária pelos órgãos da administração direta, fundos, autarquias e fundações contra a Conta Única do Tesouro. 


\section{IV.1 Pessoal e Encargos Sociais}

Valor das ordens bancárias emitidas para pagamento de pessoal e encargos sociais da administração direta, fundos, autarquias e fundações, assim como parte do pessoal do Governo do Distrito Federal e dos ex-territórios.

\section{IV.2 Benefícios Previdenciários}

Pagamento de benefícios aos aposentados, pensionistas e demais beneficiários do Regime Geral de Previdência Social pelo Tesouro Nacional, por meio de reserva bancária e de ordens bancárias emitidas em favor dos Correios e Telégrafos onde não há rede bancária.

\section{IV.3 Custeio e Capital}

São as despesas primárias da administração pública federal com custeio da máquina e realização das políticas de governo.

\section{IV.3.1 Despesas do FAT - Fundo de Amparo ao Trabalhador.}

São transferências de recursos do FAT - Fundo de Amparo ao Trabalhador - aos bancos oficiais para o pagamento de abono salarial e seguro-desemprego aos trabalhadores da iniciativa privada. Inclui também despesas com serviços bancários, treinamento de trabalhadores e com o Sine - Sistema Nacional de Emprego.

\section{IV.3.2 Subsídios e Subvenções}

São equalizações de taxas de juros e despesas administrativas relativas aos empréstimos efetuados pelas instituições financeiras aos setores agrícolas e exportador. As equalizações correspondem à diferença entre o custo de captação das instituições financeiras e a taxa do financiamento. No caso das dívidas agrícolas securitizadas pela União, é a diferença entre o valor pago às instituições financeiras do serviço dessa dívida e aquele efetuado pelos agricultores ao Tesouro Nacional.

Também inclui a despesa líquida com compra e venda de produtos agrícolas , com objetivo de regular o preço mínimo desses ativos. Por fim, inclui os subsídios implícitos destinados aos setores agrícola e industrial, além de despesas administrativas, pagos pelos Fundos Regionais (FCO, FNO, FNE). Os subsídios implícitos são calculados como sendo o custo de oportunidade desses fundos pela utilização de seus recursos nesses financiamentos, considerando o retorno potencial da aplicação dos mesmos na rede bancária.

\section{IV.3.3 Outras Despesas}

Conjunto das demais despesas primárias efetuadas pela administração pública federal. Inclui aquelas previstas no Orçamento Geral da União e as referentes ao exercício anterior, denominadas restos a pagar. 


\section{Resultado Primário do Governo Federal}

Diferença entre as receitas e despesas primárias do Tesouro Nacional e do Regime Geral de Previdência Social (RGPS). O resultado do RGPS corresponde à diferença entre as receitas da Previdência Social e as despesas com benefícios previdenciários do setor privado.

\section{Resultado Primário do Banco Central}

O déficit mensal corresponde às despesas administrativas, líquidas de receitas próprias, daquela autarquia. O resultado das demais operações do Banco Central estão incluídas nas despesas líquidas com juros nominais do Governo Central e, portanto, compõem o resultado nominal calculado pelo Banco Central com base no estoque da dívida líquida.

\section{Resultado Primário do Governo Central}

Corresponde à diferença entre as receitas e despesas primárias do Governo Central, que inclui o Tesouro Nacional, o RGPS e o Banco Central. 